\title{
Novel human polyomaviruses in human cancers
}

\author{
Citation for published version (APA):
}

Pujari, S. (2019). Novel human polyomaviruses in human cancers. [Doctoral Thesis, Maastricht University]. Maastricht University. https://doi.org/10.26481/dis.20190403sp

Document status and date:

Published: 01/01/2019

DOI:

10.26481/dis.20190403sp

Document Version:

Publisher's PDF, also known as Version of record

\section{Please check the document version of this publication:}

- A submitted manuscript is the version of the article upon submission and before peer-review. There can be important differences between the submitted version and the official published version of record.

People interested in the research are advised to contact the author for the final version of the publication, or visit the DOI to the publisher's website.

- The final author version and the galley proof are versions of the publication after peer review.

- The final published version features the final layout of the paper including the volume, issue and page numbers.

Link to publication

\footnotetext{
General rights rights.

- You may freely distribute the URL identifying the publication in the public portal. please follow below link for the End User Agreement:

www.umlib.nl/taverne-license

Take down policy

If you believe that this document breaches copyright please contact us at:

repository@maastrichtuniversity.nl

providing details and we will investigate your claim.
}

Copyright and moral rights for the publications made accessible in the public portal are retained by the authors and/or other copyright owners and it is a condition of accessing publications that users recognise and abide by the legal requirements associated with these

- Users may download and print one copy of any publication from the public portal for the purpose of private study or research.

- You may not further distribute the material or use it for any profit-making activity or commercial gain

If the publication is distributed under the terms of Article $25 \mathrm{fa}$ of the Dutch Copyright Act, indicated by the "Taverne" license above, 
Novel human polyomaviruses in human cancers 
(C) copyright Sreedhar Pujari, Maastricht 2019

Printing: ProefschriftMaken || www.proefschriftmaken.nl

ISBN 9789463803052

All rights reserved. No part of this publication may be reproduced, stored in a retrieval system or transmitted, in any form or by any means, electronic, mechanical, photocopying, recording or otherwise, without prior permission of the author or the copyright-owning journals for previous published chapters. 


\title{
Novel human polyomaviruses in human cancers
}

\author{
to obtain a doctoral degree at Maastricht University, \\ on the authority of the Rector Magnificus, Prof. dr. Rianne Letschert, \\ in accordance with the decision of the Board of Deans, \\ to be defended in public on \\ Wednesday 3 April 2019 \\ at 16.00 hours.
}

by

Sreedhar Pujari

Born on 10 June 1982 in Raketla, India 


\section{Promoter}

Prof. Dr. Axel zur Hausen

Prof. Dr. Ernst-Jan Speel

\section{Co-promoters}

Dr. Véronique Winnepenninckx

\section{Assessment committee}

Prof. dr. M.G.J Tilanus (Chairman)

Prof. dr. F.C.S Ramaekers

Prof. dr. P.H.M Savelkoul

Prof. dr. E. Stickeler, Universitätsklinikum Aachen, Aachen, Germany

Dr. A.J.C van den Brule, Jeroen Bosch Ziekenhuis, 's Hertogenbosch 


\section{List of abbreviations}

\begin{tabular}{|c|c|}
\hline AIDS & acquired immune deficiency syndrome \\
\hline ALTO & Alternatively expressed T-Ag ORF \\
\hline ATP & Adenosine triphosphate \\
\hline $\mathrm{BC}$ & basal cell carcinoma \\
\hline BKPyV & BK polyomavirus \\
\hline BLAST & basic local alignment search tool \\
\hline $\mathrm{bp}$ & base pair \\
\hline BPyV2 & Bovine polyomavirus2 \\
\hline CaPyV & Canary polyomavirus \\
\hline ChPyV & Chimpanzee polyomavirus \\
\hline CK20 & cytokeratin20 \\
\hline CLL & chronic lymphocytic leukemia \\
\hline CNS & central nervous system \\
\hline CODEHOP & Consensus Degenerate Hybrid Oligonucleotide Primer \\
\hline DLBCL & diffused large B-cell lymphoma \\
\hline DNA & deoxy ribonucleic acid \\
\hline DTS & digital transcriptome subtraction \\
\hline EBV & Epstein-Barr virus \\
\hline FBS & foetal bovine serum \\
\hline FFPE & Formalin fixed paraffin embedded \\
\hline FISH & fluorescence in situ hybridization \\
\hline $\mathrm{FL}$ & follicular lymphoma \\
\hline HBV & Hepatitis B virus \\
\hline $\mathrm{HC}$ & Hemorrhagic cystitis \\
\hline $\mathrm{HCV}$ & Hepatitis C virus \\
\hline HIV & human immunodeficiency virus \\
\hline HPV & human papillomavirus \\
\hline HPyV10 & human polyomavirus10 \\
\hline HPyV12 & human polyomavirus12 \\
\hline HPyV6 & human polyomavirus6 \\
\hline HPyV7 & human polyomavirus 7 \\
\hline HPyV9 & human polyomavirus9 \\
\hline
\end{tabular}




\begin{tabular}{|c|c|}
\hline HTLV-1 & human T-cell leukemia virus \\
\hline IARC & International Agency on Research for Cancer \\
\hline $\mathrm{IHC}$ & immunohistochemistry \\
\hline JCPyV & JC polyomavirus \\
\hline KIPyV & Karolinska institute polyomavirus \\
\hline KS & Kaposi's sarcoma \\
\hline KSHV & Kaposi's sarcoma herpesvirus \\
\hline LD PCR & Long Distance PCR \\
\hline LPyV & Lymphotropic polyomavirus \\
\hline LT-Ag & large $T$ antigen \\
\hline $\mathrm{MCC}$ & Merkel cell polyomavirus \\
\hline MCPyV & Merkel cell polyomavirus \\
\hline MDA & multiple displacement amplification \\
\hline MG & Myasthenia gravis \\
\hline mRNA & messenger ribonucleic acid \\
\hline MuPyV & Murine polyomavirus \\
\hline MWPyV & Malawi polyomavirus \\
\hline MXPyV & Mexico polyomavirus \\
\hline NCCR & non-coding control region \\
\hline NGS & next generation sequencing \\
\hline NJPyV & New jersey polyomavirus \\
\hline NLS & Nuclear localization signal \\
\hline NMSC & non-melanoma skin cancers \\
\hline NPA & nasopharyngeal aspirates \\
\hline OBD & origin binding domain \\
\hline ORF & open reading frame \\
\hline PaPyV & pan polyomavirus \\
\hline PCR & polymerase chain reaction \\
\hline PML & progressive multifocal leukoencephalopathy \\
\hline PP2A & Protein phosphotase2A \\
\hline PP4C & protein phosphatase $4 \mathrm{C}$ \\
\hline $\mathrm{pRB}$ & Retinoblastoma protein \\
\hline PVB19 & parvovirus B19 \\
\hline PVNA & polyomavirus associated nephropathy \\
\hline
\end{tabular}


RCA

SCS

$\mathrm{SSC}$

ST-Ag

StLPyV

SV40

TdT

TMA

TS

TSPYV

VP

WHIM

WUPyV
Rolling circle amplification

specimen control size

squamous cell carcinoma

small t antigen

St. louis polyomavirus

Simian virus 40

Terminal deoxynucleotidyl transferase

tissue microarray

trichodysplasia spinulosa

trichodysplasia spinulosa associated polyomavirus

viral protein

warts, hypogammaglobulinemia, infections, and myelokanthexis

Washington university polyomavirus 



\section{Contents}

\section{Chapter 1}

General introduction

\section{Chapter 2}

Frequent detection of human polyomavirus 6 in keratoacanthomas

\section{Chapter 3}

Detection of Human Polyomavirus 7 in Human Thymic Epithelial Tumors

\section{Chapter 4}

Expression of $\mathrm{pRb}$ and $\mathrm{p} 16 \mathrm{INK} 4$ in human thymic epithelial tumors in relation to the presense of human polyomavirus 7

\section{Chapter 5}

Oncogenic viruses in Skull Base Chordomas

\section{Chapter 6}

No evidence for WUPYV DNA in human lung cancers

\section{Chapter 7}

Novel degenerate oligonucleotides as discovery tool for human polyomaviruses

\section{Chapter 8}

General Discussion, Summary and Valorization

Acknowledgements

Curriculum vitae

Publications 

<smiles>C=CC1CC1</smiles> 


\title{
Chapter
}

\section{Frequent detection of human polyomavirus 6 in keratoacanthomas}

Sreedhar Pujari, Jan Beckervordersandforth, Dorit Rennspiess, Ernst Jan M. Speel, Véronique Winnepenninckx, Carlos Diaz, Wolfgang Weyers, Anke Maria Haugg, Anna Kordelia Kurz and Axel zur Hausen

\author{
Diagnostic Pathology \\ (2016) 11:58 DOI 10.1186/s13000-016-0509-z
}

Received: 16 November 2015 Accepted: 29 June 2016

Published online 07 july 2016 


\section{Abstract}

Background: The recent discovery of the Merkel cell polyomavirus and its consistent association with Merkel cell carcinoma has drawn attention to the numerous recently discovered polyomaviruses and their possible involvement in the etiopathogenesis of non-melanoma skin cancer (NMSC). Data on the recently discovered human polyomavirus 6 (HPyV6) and its role in NMSC are sparse and in part controversial.

Methods: In the present study we tested a large number $(n=299)$ of NMSC specimens for the presence of human polyomavirus 6 (HPyV6) by DNA PCR and HPyV6 fluorescence in situ hybridization (FISH). In detail, 59 keratoacanthomas (KA), 109 basal cell carcinomas (BCC), 86 squamous cell carcinomas (SCC) and 45 trichoblastomas (TB) were tested for the presence of HPyV6.

Results: HPyV6 DNA PCR and subsequent sequence analysis revealed that $25 \mathrm{KAs}$ (42.3 \%), 23 BCCs (21.1 \%), 8 SCCs (9.3\%) and 10 TBs (22.2 \%) were HPyV6 positive. The presence of HPyV6 DNA was visualized and validated on the single cell level within the histomorphological context by HPyV6 fluorescence in situ hybridization.

Conclusions: The high frequency of HPyV6 DNA in $42.3 \%$ of KA possibly points to a role for HPyV6 in the etiopathogenesis of KAs. Although the detection rate of HPyV6 DNA in BCCs and TBs is within the previously reported detection range in normal skin, it does not exclude a possible role for HPyV6 in the carcinogenesis in a significant subset of these skin tumors.

Keywords: Human Polyomavirus 6, HPyV6, Keratoacanthoma, Non melanoma skin cancer, Fluorescence in situ hybridization, FISH 


\section{Background}

Non melanoma skin cancer (NMSC) constitutes the most common group of human cancers and still its incidence is continuously rising [1, 2]. However, the under-lying etiology and molecular pathogenesis of NMSC remains in large part unresolved. Immune senescence and immunosuppression have been identified as import-ant risk factors in the pathogenesis of NMSC $[3,4]$, clearly pointing to a possible involvement of an infectious agent in NMSC etiology. In large epidemiological studies, an increased risk of cutaneous human papillomavirus (HPV) and cutaneous squamous cell carcinoma (SCC) was shown in the general population and immunosuppressed organ transplant recipients [5]. It was shown that the risk to develop squamous cell carcinoma (SCC), but not basal cell carcinoma (BCC) is associated with seropositivity for HPV [6]. Although the prevalence of the main HPV types found, i.e. $\beta$-HPV types 5 and 8 ranged between 27 and 85 \% [7], they have been dis-cussed as a possible co-factor in the early onset of cutaneous SCC, in combination with UV-induced DNA damage or immunosuppression [7]. Next to HPV, 13 human polyomaviruses (HPyV) are known (reviewed in [8,9], of which 11 have been recently identified in neo-plastic and non-neoplastic skin samples [10-14] and in other patient materials $[9,15-18]$. Yet, no conclusive data for a role of the continuously growing number of human polyomaviruses in NMSC are available. Ever since their first detection, HPyV have repeatedly been incriminated with the etiopathogenesis of human cancers. However, only the recently discovered Merkel cell polyomavirus (MCPyV) has been identified as a new human tumor virus which is based on the consistent detection of integrated MCPyV DNA in the majority of Merkel cell carcinomas (MCC), a highly malignant NMSC [10-12]. In addition, tumor specific mutations within the large T antigen (LTag) of MCPyV are found in MCCs [13].

In 2010, human polyomavirus 6 (HPyV6) was isolated from skin swabs of healthy patients and characterized, but yet could not be linked to the pathogenesis of any human disease [14]. Although seroprevalence indicates that HPyV6 infection is common in adults, ranging from 69 to $76 \%[14,19,20]$, it is detected in skin swabs of normal skins only between 14.3 and $27.6 \%[14,21]$. Studies reporting the presence of HPyV6 DNA in NMSC are sparse [22-25], and in part controversial [21, 26, 27] (Table 1). Recently, a case of a keratoacanthoma (KA) which developed during treatment with Vemurafenib in a BRAF V600E positive melanoma patient was tested positive for the presence of HPyV6 [28] with pronounced viral load. In the present study we assessed the presence of HPyV6 DNA in a large number of NMSC specimens $(n=299)$, using HPyV6 DNA-PCR. In addition, we were able to visualize and validate the presence of HPyV6 DNA on the single cell level in a subset of HPyV6 DNA positive KAs, BCCs and SCCs by using fluorescence in situ hybridization (FISH). 
Table 1 Summary of clinicopathological data and results of molecular investigation of non-melanoma skin cancer

\begin{tabular}{|c|c|c|c|c|c|c|}
\hline References & Tumor type & HPyV6 DNA & Detection Method & $\begin{array}{l}\text { HPyV6 IHC } \\
6 \text { V32 }\end{array}$ & HPy & $\begin{array}{l}\text { Clinical } \\
\text { Data }\end{array}$ \\
\hline \multirow{2}{*}{$\begin{array}{l}\text { Schowalter et al. } \\
{[14]}\end{array}$} & $N S(n=35)$ & $14,3 \%$ & DNA-PCR & NA & NA & IC \\
\hline & $\operatorname{Ser}(n=65)$ & $69 \%$ & VP1 ELISA & & & NA \\
\hline $\begin{array}{l}\text { Duncavage et al. } \\
{[22]}\end{array}$ & $\operatorname{MCC}(n=28)$ & ) $3,5 \%$ & rt-PCR & NA & NA & NA \\
\hline \multirow{3}{*}{$\begin{array}{l}\text { Schrama et al. } \\
{[24]}\end{array}$} & $\operatorname{SCC}(n=21)$ & $38 \%$ & qPCR & NA & NA & NA \\
\hline & $\operatorname{BCC}(n=18)$ & $5,5 \%$ & & & & \\
\hline & $\operatorname{MCC}(n=20)$ & ) $10 \%$ & & & & \\
\hline \multirow[t]{3}{*}{ Scola et al. [25] } & $\operatorname{SCC}(n=52)$ & $4 \%$ & rt-PCR & NA & NA & IC \\
\hline & $\operatorname{BCC}(n=41)$ & $7 \%$ & & & & \\
\hline & $\mathrm{KA}(\mathrm{n}=42)$ & $5 \%$ & & & & \\
\hline \multirow{3}{*}{ Imajoh et al. [23] } & NS $(n=34)$ & $8,8 \%$ & rt-PCR & NA & NA & NA \\
\hline & $\operatorname{SCC}(n=63)$ & $3,2 \%$ & & & & \\
\hline & $B C C(n=50)$ & $2 \%$ & & & & \\
\hline \multirow[t]{4}{*}{ Nicol et al. [19] } & Ser & \multicolumn{2}{|c|}{$37,5 \%$ pos. (age $1-4$ )VP1 ELISA } & NA & NA & IC \\
\hline & & \multicolumn{2}{|l|}{$\begin{array}{l}61,8 \% \text { pos. (age } 15- \\
19)\end{array}$} & & & \\
\hline & & \multicolumn{2}{|l|}{$\begin{array}{l}67,1 \% \text { pos (age } 30- \\
38 \text { ) }\end{array}$} & & & \\
\hline & & \multicolumn{2}{|l|}{$98,2 \%$ pos. (age $80+$ ) } & & & \\
\hline $\begin{array}{l}\text { Schrama et al. } \\
\text { [28] }\end{array}$ & $\mathrm{KA}(\mathrm{n}=4)$ & $25 \%$ & rt-PCR & KA $1 / 4(25 \%$ & ) $N A$ & IS \\
\hline
\end{tabular}

IS immunosuppressed, IC immunocompetent, PCR polymerase chain reaction, IHC immunohistochemistry, FISH fluorescence in situ hybridization, rt-PCR real time

PCR, qPCR quantitative PCR, ELISA enzyme-linked immunosorbent assay, HPyV6 human polyomavirus 6, NS normal skin, Ser serum, SCC squamous cell carcinoma,

BCC basal cell carcinoma, KA keratoacanthoma, MCC Merkel cell carcinoma, NA not applicable

\section{Methods}

\section{Patients and tissues}

Formalin-fixed and paraffin-embedded (FFPE) tissues of 299 skin excisions or biopsies were included in this study. All respective samples had been excised for diagnostic and/or therapeutic reasons. $51 \mathrm{BCC}, 29 \mathrm{KA}$ and $86 \mathrm{SCC}$ were obtained from the Maastricht Pathology Tissue Collection (MPTC) and 58 BCC, 30 KA and 45 TB were obtained from the Center for Dermato-pathology, Freiburg, Germany. 


\section{DNA extraction}

First, an H\&E stain of the selected specimens was reviewed by four experienced pathologists (A.z.H., V.W. C.D., W.W.) to select paraffin material containing $>95 \%$ tumor tissue. Two consecutive $5 \mu \mathrm{m}$ thick paraffin sections from each specimen were subjected to DNA ex-traction. In brief, after deparaffinization, the tissues were lysed by proteinase $\mathrm{K}$ overnight $\left(56^{\circ} \mathrm{C}\right)$ until complete tissue lysis, and DNA was extracted using the DNeasy Tissue kit (Qiagen). Purified DNA was measured in a spectrophotometer (Nano-drop, 2000, Thermo Scientific) and directly used for PCR. DNA quality and integrity were assessed by specimen control size (SCS) ladder as described [29].

\section{HPYV6 DNA-PCR}

PCR was performed with 150 ng of genomic DNA using the AmpliTaq Gold (Roche) DNA polymerase in a final volume of $50 \mu \mathrm{l}$. For detection of HPyV6, primer sets, and PCR conditions were used as described earlier [14]. Water instead of DNA template was used for PCR-negative controls containing all other PCR components.

\section{HPyV6 DNA sequence analyses}

PCR products were submitted to automated nucleotide sequencing in an $A B I 3130 X L$ genetic analyzer ( $\mathrm{ABI}$ ). DNA sequences were compared and analyzed with the reference sequences of the National Center for Biotechnology Information (NCBI) Entrez Nucleotide Database gb gb|HM011563.1| (HPyV6 isolate 627a) and gb|HM011561.1| (HPyV6 isolate 607b) using the NCBI Blast program. Multiple sequence alignments were performed with Clustal omega (EMBL-EBI-2014).

\section{Detection of HPYV6 by fluorescence in situ hybridization (FISH)}

FISH was performed as described earlier [30-32]. In brief, deparaffinized $3 \mu \mathrm{m}$ thick tissue sections were pre-treated with $0.2 \mathrm{M} \mathrm{HCl}$, incubated with $1 \mathrm{M} \mathrm{NaSCN}$ and digested with 0.5 mg/ml pepsin (2500-3500 U/mg, Sigma Chemical, St. Louis, MO). The digoxigenin labelled specific whole genome HPyV6 DNA probe was generated by Nick translation from the pHPyV6-607 (gift from Christopher Buck Addgene plasmid \# 24727) and added to the samples in a hybridization mixture, containing a concentration of $5 \mathrm{ng} / \mu \mathrm{l}$, followed by denaturation of probe and tissue DNA $\left(5 \mathrm{~min}, 80^{\circ} \mathrm{C}\right)$ and hybridization overnight $\left(37^{\circ} \mathrm{C}\right.$, humid chamber, Thermobrite, Abbott, IL). Unbound HPyV6 DNA probe was stringently washed away. Bound probe was detected by sequential incubation of the following secondary antibody conjugates: Rhodamine labeled sheep anti digoxigenin antibody (1:100; Roche, Basel, Switzerland) and Texas red labeled donkey anti sheep secondary anti-body (Brunschwig Chemie, Amsterdam, Netherlands). Prior to incubation, a specific binding sites where blocked with Boehringer Blocking reagent (Roche). Cell nuclei were counterstained with 4.6-diamidino-2-pheny-lindole dihydrochloride (DAPI; $0.2 \mu \mathrm{g} / \mathrm{ml}$, 
Vectashield, Vector Laboratories, CA). Signals were visualized using a DM 5000B fluorescence microscope (Leica, Wetzlar, Germany) coupled to an digital camera (Leica DC $300 \mathrm{Fx}$ ) for independent evaluation of FISH signals by 4 investigators ( $\mathrm{AzH}, \mathrm{AMH}, \mathrm{EJS}$, DR) according to criteria described earlier [31,33].

\section{Results}

\section{HPYV6-DNA PCR}

The DNA quality and integrity of extracted genomic DNA was assessed by specimen control size (SCS) lad-der analysis (Figure. 1a) as described earlier [29]. All samples included in this study revealed sufficient DNA quality in order to test for HPyV6 by DNA PCR (Figure. 1a). HPyV6 DNA-PCR directed against the large T antigen (LTAg) of the HPyV6 genome revealed specific PCR products in 25/59 (42.3\%) of KA (Figure. 1b), 8/86 (9.3\%) of SCC, 23/109 (21.1\%) of BCC, and 10/45 (22.2\%) of TB. All PCR products were sequenced and confirmed the presence of HPyV6, revealing only minor nucleotide changes (<2\%).

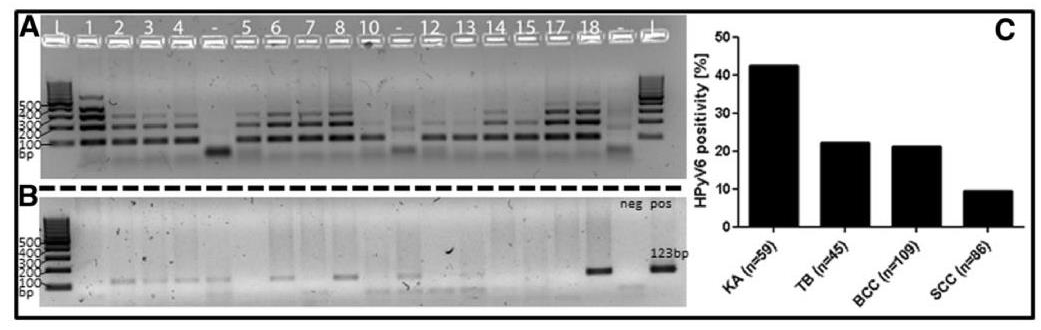

Figure $12 \%$ agarose gel showing the specimen control size (SCS) ladder HPyV6 DNA-PCR and SCS ladder for keratoacanthoma (KA), results HPyV6 DNA-PCR: a reveals adequate DNA quality of KA in order to proceed with HPyV6 testing. b HPyV6 DNA PCR results of selected KA, showing amplification of the 123 bp fragment of the VP1 gene (123 bp) while using the primers according to Schowalter et al. [12] with the 123 pb positive control. c Summary of the HPyV6-DNA PCR results on (KA), trichoblastoma (TB), basal cell carcinoma (BCC) and squamous cell carcinoma (SCC)

\section{HPyV6-FISH}

In total, 26 KA were tested by HPyV6 FISH, including 13 HPyV6 DNA PCR positive cases and 13 negative cases. In none of the HPyV6 DNA negative KA specific HPyV6 fluorescence signals were found in the tumor cell nuclei. Out of 13 HPyV6 DNA positive KA, 8 (61.5 \%) showed specific positive signals in the HPyV6 FISH. HPyV6 FISH hybridization signals were restricted to the mid- and upper epithelial layers of the KAs (Figure. 2a). In addition to these, specific dot-like signals in the keratin mass of the tumor (Figure. 2c) were seen. The positive FISH signals were restricted to the tumor areas, no specific signals were seen in the adjacent non-neoplastic epidermis. In dermal and subcutaneous tissue, specific 
HPyV6 FISH signals were found in perivascular and periadnexial lymphocytes (data not shown).

Pretreatment of the slides with DNAse lead to the dis-appearance of the specific HPyV6 FISH signals thus con-firming the specificity of the hybridization signals. There was a highly significant correlation between HPyV6 DNA PCR and HPyV6 FISH results ( $p=$ 0.0007; Fisher's exact test).

Out of 8 HPyV6 DNA PCR positive SCC, 2 were analysed by HPyV6 FISH. In both cases, specific nuclear HPyV6 hybridization signals were seen within the tumor cells.

Also 5 of the HPyV6 DNA positive BCCs were subjected to HPyV6 FISH. In 4 out of the 5 HPyV6 DNA positive cases the presence of HPyV6 DNA was con-firmed by HPyV6 FISH. HPyV6 FISH revealed the specific punctate nuclear hybridization pattern within the basaloid tumor cells (Figure. 3). This specific dot-like pat-tern was not seen in the adjacent non neoplastic tissues.

Also here we could confirm the specificity of the used HPyV6 FISH probe by DNAse pretreatment.
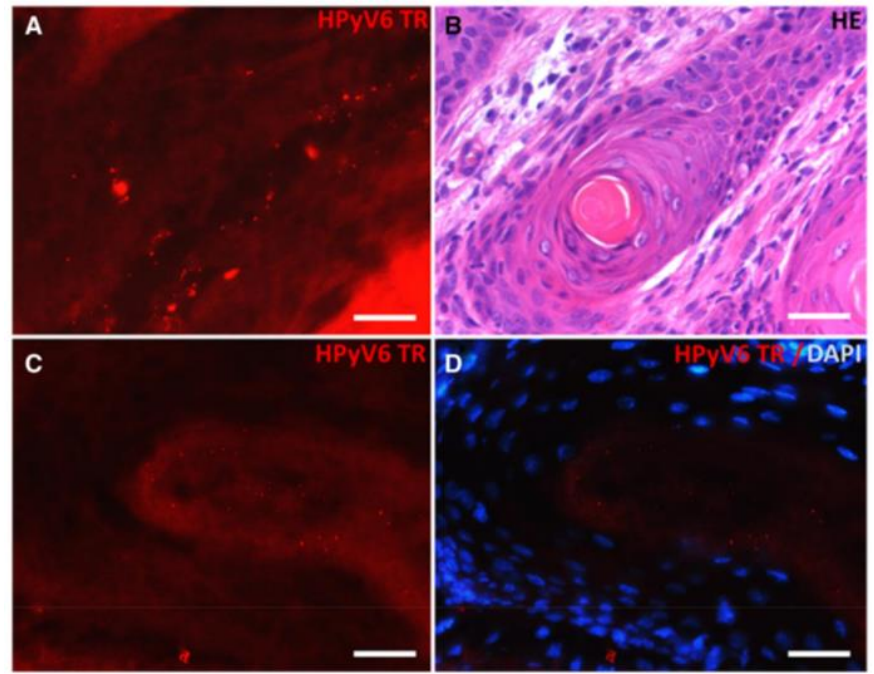

Figure. 2 Photomicrographs of a representative example of the presence of HPyV6 detected by FISH in a keratoacanthoma: a DNA sequence nuclear hybridization signals in the keratinocytes of the lesion (red), located mainly in the middle and upper epidermis (scale bar $30 \mu \mathrm{m}$ ). b HE staining of keratoacanthoma used for HPyV6 FISH. c DNA sequence nuclear hybridization signals with dot-like specific positivity in the keratin layer of the lesion (red) (scale bar $30 \mu \mathrm{m}$ ). d overlay DAPI staining of nuclei of keratinocytes (blue) of the area of the lesion shown in $\mathrm{C}$, showing no nuclei in the keratin layer with the positive FISH signals 

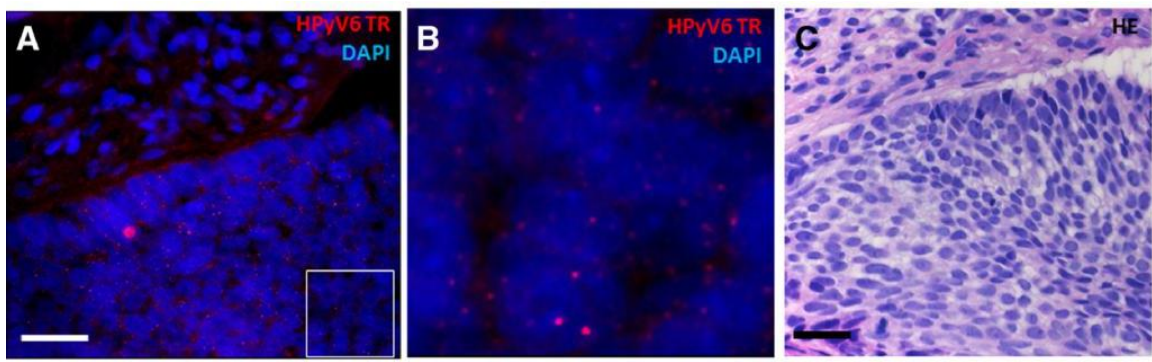

Figure. 3 Photomicrographs of a representative example of HPyV6 detected by FISH in BCC: a Nuclear HPyV6 DNA hybridization signals in the epithelial tumor cells of a BCC (red), DAPI staining the nuclei (scale bar $30 \mu \mathrm{m}$ ). b Magnification of the marked quadrangular area in a. c HE staining of BCC used for HPyV6 FISH detection (scale bar $30 \mu \mathrm{m})$

\section{Discussion}

Although major contributions to the understanding of the pathogenesis of NMSC have been made in the past de-cades, the etiology of most NMSC remains elusive. The discovery of the Merkel cell polyomavirus in 2008 and its role in the etiopathogenesis of Merkel cell carcinoma has drawn the attention to the continuously growing number of newly characterized human polyomaviruses [10-13] (reviewed in [8]).

In the present study we aimed to comprehensively assess the presence of HPyV6 DNA in a large cohort of NMSC by testing tumor specimens by HPyV6 DNA PCR. Previous studies, mainly using rtPCR/qPCR [19, 21-27] (Table 1) in smaller NMSC cohorts revealed variable positivity for HPyV6 in diverse types of NMSC with varying viral copy numbers, suggesting no evident pathological role of HPyV6 in NMSC. It is of interest that by using HPyV6 DNA PCR in this study we were able to detect more HPyV6 DNA positive NMSC as previously reported (Table 1). In addition, we established an HPyV6-specific FISH on formalin fixed and paraffin embedded material. The HPyV6 FISH enabled us to visualize the HPyV6 DNA on the single cell level within the histomorphological context of the diverse types of NMSCs.

Yet, the HPyV6 status of KA had solely been investigated in one larger study of 42 cases, showing only 2 positive cases (5\%) [25]. The underlying explanations for the obviously discrepant results with the present of HPyV6 prevalence in KA is difficult to understand. It seems unlikely that the difference is due to technical rea-sons since in the other study qPCR was used, which has been shown to provide a comparable sensitivity as the DNA PCR used in the present study. Most likely the se-lection of the targeted sequence of the HPyV6 genome impacts the detection rate of HPyV6 in these skin lesions. In this study we used primers targeting the LTAg region of HPyV6, according to Schowalter et al. [14]. Duncavage et al. [22] used three different qPCR targeting two times different regions of 
the LT-AG and one time the VP1 region, Schrama et al. [24] used qPCR tar-geting the LTAg, Imajoh et al. [23] used qPCR targeting the LTAg and the VP3 region and Schrama et al. [28] used PPCR targeting the VP3 region.

Of interest, Schrama et al. [28] investigated the presence of HPyV6 in Vemurafenib induced epithelial proliferations. Vemurafenib is a BRAF-specific inhibitor used in the therapy of BRAF mutated melanoma patients (reviewed in [34]). The authors reported a HPyV6 positive KA, which developed under Vemurafenib therapy in a BRAF V600E positive melanoma patient, with a pronounced viral load. Since multiple studies have reported that KA and SCC are one of the most frequent severe adverse side effects due to Vemurafenib this is of particular interest (reviewed in [35]). It has recently been described that HPV can cooperate with Vemurafenib to promote the initiation of some cutaneous tumors [36], which basically might be postulated for HPyV6 in KAs as well. Furthermore, KA frequently occur and relapse under immunosuppression [4], which relates the occurrence of these tumor to an impaired immune system.

The high prevalence of HPyV6 in KA in our study may point to HPyV6 playing a pathogenic role in the development of cutaneous malignancies in the context of immune suppression or immune senescence. This is indirectly supported by the rather infrequent finding of HPyV6 in other NMSC.

The HPyV6-specific FISH hybridization pattern in KA, i.e. its presence in mid- and upper epithelial part and within the keratine layer, resembles a pattern which has previously been described for some human papilloma vi-ruses (HPV) in skin tumors [37]. It has been shown that HPV DNA is commonly found in superficial layers of skin tumor lesions but is not necessarily present throughout the whole tumor [38]. This may contribute to a low viral load in the proliferative active cells. During maturation of these cells the viral load increases and exceeds the detection limit, becoming detectable in the superficial layers of the tumor lesion.

Also the HPyV6 status in SCC has recently been investigated in 3 different studies, reporting a broad variation in positivity, ranging between $3.2 \%$ [23] and $38 \%$ [24]. In all the three studies rtPCR/qPCR was used to detect HPyV6 DNA. In the present study, $9.3 \%$ of tested SCC were positive for HPyV6. These values are closer to the data of Scola et al. [25] and Imajo et al. [23] who found HPyV6 DNA in 3.2 and $4 \%$ of the SCC samples. In comparison with the other tumors we investigated, the prevalence of HPyV6 in SCC is rather low, lower [14] or comparable [23] to the prevalence of HPyV6 in normal skin, suggesting no pathological role in the development of SCC in immune competent patients.

The prevalence of HPyV6 in BCC is of interest be-cause three different studies reported HPyV6 positivity ranging between $2 \%$ [23] and $7 \%$ [25]. In all these studies the presence of HPyV6 was assessed by qPCR, whereas we used the HPyV6 DNA PCR according to Schowalter et al. [14]. Beside BCC, we also tested HPyV6 in TB which yet had not been 
done before. TB are benign neoplasms of follicular differentiation, which share several histomorphological features with nodular BCC, thus hampering the ease of histomorphological diagnostics in certain circumstances [39]. In our study $21.1 \%$ of BCC and $22.2 \%$ of TB were shown to harbor HPyV6 DNA. A study [14] using HPyV6 DNA PCR, showed that skin swabs of healthy donors were in $14.3 \%$ positive for HPyV6 DNA. This may suggest that the choice of the target sequence used in qPCR might contribute to the different results in comparison to our findings, generated by using conventional DNA PCR. To validate these positive results, we combined the HPyV6 DNA PCR with HPyV6 FISH also in BCC and found HPyV6 specific hybridization signals within the BCC tumor cells (Figure. 3).

\section{Conclusions}

We demonstrate the presence of HPyV6 DNA in a large cohort of NMSC by PCR and HPyV6 FISH. The intro-duction of an HPyV6-specific FISH on FFPE tissues is a powerful tool to analyze the presence of HPyV6 DNA on the single cell level within the histomorphological context. We identified HPyV6 frequently in KA, and in a significant subset of BCC and TB and to a far lesser extent in SCC. The significant association with KA is remarkably, as the virus reveals a distribution pattern that has been described for pathogenic HPV infection in skin tumors. The high frequency of HPyV6-DNA in $42.3 \%$ of KA might point to a role for HPyV6 in the etiopathogenesis of KAs. It would be highly interesting to test a larger number of Vemurafenib induced KAs and SCCs for the presence of HPYV6. In addition, HPyV6 might play a role in the carcinogenesis of a significant subset of BCC and TB.

\section{Abbreviations}

$\mathrm{BCC}$, basal cell carcinoma; FISH, fluorescence in situ hybridization; HE, hematoxylin eosin; HPV, human papillomavirus; HPyV6, human polyomavirus 6; HPyV7, human polyomavirus 7; KA, keratoacanthoma; LT-Ag, large T-antigen; MCC, Merkel cell carcinoma; MCPyV, Merkel cell polyomavirus; NMSC, non-melanocytic skin cancer; SCC, squamous cell carcinoma; SCS, specimen control size; TB, trichoblastoma; VP1, Viral protein 1; VP3, Viral protein 3.

\section{Acknowledgements}

All substantial contributions to this study are mentioned in the author's contributions. All authors are employees of the Maastricht University Medical Centre, Maastricht, The Netherlands. We thank E. Chteinberg, M.sc., for his excellent technical support. 


\section{Funding}

Extramural funding: not applicable.

\section{Availability of data and materials}

Most data are included in the author's manuscript. Data not included are marked as data not shown and are part of other data sets containing data not relevant for this study.

\section{Authors' contributions}

$J B, S P$ and DR participated in the design of the study and carried out the experiments. CD, WW, VW and $\mathrm{AzH}$ reviewed the histopathology and $\mathrm{VW}, \mathrm{EJS}, \mathrm{AMH}$ and $\mathrm{AZH}$ read the immunohistochemistry and FISH analyses. JB, SP, DR, AMH, AKK wrote the manuscript. $\mathrm{AzH}$ is the principal investigator and designed and supervised the study and helped writing the manuscript. All authors read and approved the final manuscript.

\section{Competing interests}

The authors declare that they have no competing interests.

\section{Consent for publication}

Not applicable.

\section{Ethics approval and consent to participate}

All use of tissue and patient data was in agreement with the Dutch Code of Conduct for Observational Research with Personal Data (2004) and Tissue (2001, www.fmwv.nl). Archived samples were obtained from the Maastricht Pathology Tissue Collection and the Center for Dermatopathology, Freiburg, Germany (approved by the ethical review board of the Institution (nr. 267/08)). 


\section{Author details}

${ }^{1}$ Department of Pathology, GROW-School for Oncology \& Developmental Biology, Maastricht University Medical Center, P. Debyelaan 25, P.O. Box 5800, 6202 AZ Maastricht, The Netherlands.

${ }^{2}$ Center for Dermatopathology, Freiburg, Germany.

${ }^{3}$ Medizinische Klinik IV, Universitätsklinikum Aachen, Aachen, Germany.

Received: 16 November 2015 Accepted: 29 June 2016

Published online 07 july 2016 


\section{References}

1. Diepgen TL, Mahler V. The epidemiology of skin cancer. Br J Dermatol. 2002;146 Suppl 61:1-6.

2. Hoey SE, Devereux CE, Murray L, Catney D, Gavin A, Kumar S, et al. Skin cancer trends in Northern Ireland and consequences for provision of dermatology services. Br J Dermatol. 2007;156:1301-7.

3. Diffey BL, Langtry JA. Skin cancer incidence and the ageing population. Br J Dermatol. 2005;153:679-80.

4. Walder BK, Robertson MR, Jeremy D. Skin cancer and immunosuppression. Lancet. 1971;2:1282-3.

5. Nindl I, Stockfleth E, Hofmann TG. Report on the 6th International Conference of HPV, Polyomavirus, and UV Radiation in Skin Cancer. J Invest Dermatol. 2013;133:1702-5.

6. Karagas MR, Nelson HH, Sehr P, Waterboer T, Stukel TA, Andrew A, et al. Human papillomavirus infection and incidence of squamous cell and basal cell carcinomas of the skin. J Natl Cancer Inst. 2006;98:389-95.

7. Nindl I, Gottschling M, Stockfleth E. Human papillomaviruses and non-melanoma skin cancer: basic virology and clinical manifestations. Dis Markers. 2007;23:247-59.

8. DeCaprio JA, Garcea RL. A cornucopia of human polyomaviruses. Nat Rev Microbiol. 2013;11:264-76.

9. Mishra N, Pereira M, Rhodes RH, An P, Pipas JM, Jain K, et al. Identification of a Novel Polyomavirus in a Pancreatic Transplant Recipient With Retinal Blindness and Vasculitic Myopathy. J Infect Dis. 2014;210:1595-9.

10. Feng $H$, Shuda $M$, Chang $Y$, Moore PS. Clonal integration of a polyomavirus in human Merkel cell carcinoma. Science. 2008;319:1096-100.

11. Kassem A, Schopflin A, Diaz C, Weyers W, Stickeler E, Werner M, et al. Frequent detection of Merkel cell polyomavirus in human Merkel cell carcinomas and identification of a unique deletion in the VP1 gene. Cancer Res. 2008;68:5009-13.

12. Becker JC, Houben R, Ugurel S, Trefzer U, Pfohler C, Schrama D. MC polyomavirus is frequently present in Merkel cell carcinoma of European patients. J Invest Dermatol. 2009;129:248-50.

13. Shuda M, Feng H, Kwun HJ, Rosen ST, Gjoerup O, Moore PS, et al. T antigen mutations are a human tumorspecific signature for Merkel cell polyomavirus. Proc Natl Acad Sci U S A. 2008;105:16272-7.

14. Schowalter RM, Pastrana DV, Pumphrey KA, Moyer AL, Buck CB. Merkel cell polyomavirus and two previously unknown polyomaviruses are chronically shed from human skin. Cell Host Microbe. 2010;7:509-15.

15. van der Meijden E, Janssens RW, Lauber C, Bouwes Bavinck JN, Gorbalenya AE, Feltkamp MC. Discovery of a new human polyomavirus associated with trichodysplasia spinulosa in an immunocompromized patient. PLoS Pathog. 2010;6:e1001024.

16. Scuda N, Hofmann J, Calvignac-Spencer S, Ruprecht K, Liman P, Kuhn J, et al. A novel human polyomavirus closely related to the african green monkey-derived lymphotropic polyomavirus. J Virol. 2011;85:4586-90.0

17. Siebrasse EA, Reyes A, Lim ES, Zhao G, Mkakosya RS, Manary MJ, et al. Identification of MW polyomavirus, a novel polyomavirus in human stool. J Virol. 2012;86:10321-6.

18. Lim ES, Reyes A, Antonio M, Saha D, Ikumapayi UN, Adeyemi M, et al. Discovery of STL polyomavirus, a polyomavirus of ancestral recombinant origin that encodes a unique $\mathrm{T}$ antigen by alternative splicing. Virology. 2013;436:295-303.

19. Nicol JT, Robinot R, Carpentier A, Carandina G, Mazzoni E, Tognon M, et al. Age-specific seroprevalences of merkel cell polyomavirus, human polyomaviruses 6,7 , and 9, and trichodysplasia spinulosa-associated polyomavirus. Clin Vaccine Immunol: CVI. 2013;20:363-8.

20. van der Meijden E, Bialasiewicz S, Rockett RJ, Tozer SJ, Sloots TP, Feltkamp MC. Different serologic behavior of MCPYV, TSPYV, HPyV6, HPyV7 and HPyV9 polyomaviruses found on the skin. PLoS One. 2013;8:e81078.

21. Wieland $U$, Silling $S$, Hellmich M, Potthoff A, Pfister $H$, Kreuter A. Human polyomaviruses 6, 7, 9, 10 and Trichodysplasia spinulosa-associated polyomavirus in HIV-infected men. J Gen Virol. 2014;95:928-32.

22. Duncavage EJ, Pfeifer JD. Human polyomaviruses 6 and 7 are not detectable in Merkel cell polyomavirusnegative Merkel cell carcinoma. J Cutan Pathol. 2011;38:790-6. 
23. Imajoh M, Hashida Y, Nakajima H, Sano S, Daibata M. Prevalence and viral DNA loads of three novel human polyomaviruses in skin cancers from Japanese patients. J Dermatol. 2013;40:657-60.

24. Schrama D, Buck CB, Houben R, Becker JC. No evidence for association of HPyV6 or HPyV7 with different skin cancers. J Invest Dermatol. 2012;132:239-41.

25. Scola N, Wieland U, Silling S, Altmeyer P, Stucker M, Kreuter A. Prevalence of human polyomaviruses in common and rare types of non-Merkel cell carcinoma skin cancer. Br J Dermatol. 2012;167:1315-20.

26. Du-Thanh A, Guillot B, Dereure O, Foulongne V. Detection of Merkel cell polyomavirus's and other human polyomaviruses' DNA in lesional and non-lesional skin from Kaposi's Sarcoma patients. Br J Dermatol. 2015:n/a-n/a.

27. Fava P, Merlino C, Novelli M, Ponti R, Galliano I, Montanari P, et al. HPyV6, HPyV7 and TSPyV DNA sequences detection in skin disease patients and healthy subjects. J Eur Acad Dermatol Venereol. 2015:n/a-n/a.

28. Schrama D, Groesser L, Ugurel S, Hafner C, Pastrana DV, Buck CB, et al. Presence of Human Polyomavirus 6 in Mutation-Specific BRAF Inhibitor-Induced Epithelial Proliferations. JAMA Dermatol. 2014;150:1180-6.

29. van Dongen JJ, Langerak AW, Bruggemann M, Evans PA, Hummel M, Lavender FL, et al. Design and standardization of PCR primers and protocols for detection of clonal immunoglobulin and T-cell receptor gene recombinations in suspect lymphoproliferations: report of the BIOMED-2 Concerted Action BMH4CT98-3936. Leukemia. 2003;17:2257-317.

30. Haugg AM, Speel EJ, Pantulu ND, Pallasch C, Kurz AK, Kvasnicka HM, et al. Fluorescence in situ hybridization confirms the presence of Merkel cell polyomavirus in chronic lymphocytic leukemia cells. Blood. 2011;117:5776-7.

31. Haugg AM, Rennspiess D, Zur Hausen A, Speel EJ, Cathomas G, Becker JC, et al. Fluorescence in situ hybridization and qPCR to detect Merkel cell polyomavirus physical status and load in Merkel cell carcinomas. Int J Cancer. 2014;135:2804-15.

32. Hopman AH, Kamps MA, Smedts F, Speel EJ, Herrington CS, Ramaekers FC. HPV in situ hybridization: impact of different protocols on the detection of integrated HPV. Int J Cancer. 2005;115:419-28.

33. Hafkamp HC, Manni JJ, Haesevoets A, Voogd AC, Schepers M, Bot FJ, et al. Marked differences in survival rate between smokers and nonsmokers with HPV 16-associated tonsillar carcinomas. Int J Cancer. 2008;122:2656-64.

34. Garbe C, Abusaif S, Eigentler TK. Vemurafenib. Recent Results Cancer Res. 2014;201:215-25.

35. Ma C, Armstrong AW. Severe adverse events from the treatment of advanced melanoma: a systematic review of severe side effects associated with ipilimumab, vemurafenib, interferon alfa-2b, dacarbazine and interleukin-2. J Dermatolog Treat. 2014;25:401-8.

36. Holderfield M, Lorenzana E, Weisburd B, Lomovasky L, Boussemart L, Lacroix L, et al. Vemurafenib cooperates with HPV to promote initiation of cutaneous tumors. Cancer Res. 2014;74:2238-45.

37. Forslund O, Lindelof B, Hradil E, Nordin P, Stenquist B, Kirnbauer R, et al. High prevalence of cutaneous human papillomavirus DNA on the top of skin tumors but not in "Stripped" biopsies from the same tumors. J Invest Dermat. 2004;123:388-94.

38. Kurzen H, Esposito L, Langbein L, Hartschuh W. Cytokeratins as markers of follicular differentiation: an immunohistochemical study of trichoblastoma and basal cell carcinoma. Am J Dermatopathol. 2001;23:501-9.

39. Savage JA, Maize Sr JC. Keratoacanthoma clinical behavior: a systematic review. Am J Dermatopathol. 2014;36:422-9. 


\section{Chapter}

\section{Detection of Human Polyomavirus 7 in Human Thymic Epithelial Tumors}

Sreedhar Pujari, Dorit Rennspiess, Marlies Keijzers, Myrurgia A. Abdul-Hamid, Monique Hochstenbag, Anne-Marie Dingemans, Anna Kordelia Kurz, Ernst-Jan Speel, Anke Haugg, Diana V. Pastrana, Christopher B. Buck, Marc H. De Baets, and Axel zur Hausen

Journal of Thoracic Oncology ${ }^{\circledR}$ Volume 10, Number 2, February 2015 


\section{Abstract}

Introduction: Although the molecular genetics possibly underlying the pathogenesis of human thymoma have been extensively studied, its etiology remains poorly understood. Because murine polyoma-virus consistently induces thymomas in mice, we assessed the presence of the novel human polyomavirus 7 (HPyV7) in human thymic epithelial tumors.

Methods: HPyV7-DNA Fluorescence in situ hybridization (FISH), DNA-polymerase chain reaction $(\mathrm{PCR})$, and immunohistochemistry $(\mathrm{IHC})$ were performed in 37 thymomas. Of these, 26 were previously diagnosed with myasthenia gravis (MG). In addition, 20 thymic hyperplasias and 20 foetal thymic tissues were tested.

Results: HPyV7-FISH revealed specific nuclear hybridization signals within the neoplastic epithelial cells of 23 thymomas (62.2\%). With some exceptions, the HPyV7-FISH data correlated with the HPyV7-DNA PCR. By IHC, large T antigen expression of HPyV7 was detected, and double staining confirmed its expression in the neoplastic epithelial cells. Eighteen of the 26 MG-positive and 7 of the 11 MG-negative thymomas were HPyV7positive. Of the 20 hyperplastic thymi, 40\% were HPyV7-positive by PCR as confirmed by FISH and IHC in the follicular lymphocytes. All 20 fetal thymi tested HPyV7-negative.

Conclusions: The presence of HPyV7-DNA and large T antigen expression in the majority of thymomas possibly link HPyV7 to human thymomagenesis. Further investigations are needed to elucidate the possible associations of HPyV7 and MG.

Key Words: Human polyomavirus 7, thymomas, thymic follicular hyperplasia, viral tumorigenesis, myasthenia gravis 
The autoimmune disease myasthenia gravis (MG) has been associated with thymomas and follicular hyperplasia.

Moreover, the role of viral infections has been implicated in this disease. There have been several studies on the molecular genetics possibly underlying the pathogenesis of thymomas, that is, epithelial thymic neoplasias admixed with a variable non-neoplastic lymphoid component. ${ }^{1,2}$ However, the etiology of human thymoma remains poorly understood. Over the last two decades, the possible involvement of the oncogenic $\gamma$ herpesvirus Epstein-Barr (EBV) has proved debatable. ${ }^{3-7}$

Next to EBV, polyomavirus infection has been implicated in the etiology of thymomas, based on the consistent finding that the polyomavirus strain PTA induces thymomas in mouse strains $\mathrm{C} 3 \mathrm{H} / \mathrm{BiDa}$ and AKR. ${ }^{8,9}$ Polyomaviruses are small circular double-stranded DNA viruses which have been extensively used to study cell transformation in vitro and tumorigenesis in animal models. In recent years, a number of new human polyomaviruses have been identified, giving a current total of $12 .{ }^{10-12}$ Yet, only the Merkel cell polyomavirus (MCPyV), discovered in 2008, has been identified as a new human tumor virus. ${ }^{13}$ MCPyV has been shown to be present in approximately $80 \%$ of Merkel cell carcinomas (MCCS), which are highly malignant neuroendocrine carcinomas of the skin. ${ }^{14,15}$ In these, MCPyV is clonally integrated in the tumor genome, and tumorspecific oncogenic mutations within the viral genome have been identified. ${ }^{13,16}$ Recently, polyomaviruses 6 and 7 (HPyV6 and 7) have been isolated from skin samples and characterized, but have yet not been associated with any human disease. ${ }^{17}$ However, seroprevalence of HPyV 6 and 7 indicates that infection is common in humans, that is, $69 \%$ and $35 \% .{ }^{17}$ A recent study has shown that the seroprevalence of HPyV7 reveals a regularly age-related increase, with less than $10 \%$ in the age group below 4 years and approximately $45 \%$ in the age group $10-14$ years, reaching approximately $64 \%$ in adults. ${ }^{18}$ On the basis of an initial DNA polymerase chain reaction (PCR) screening testing for the presence of novel polyomaviruses in diverse human cancers, we assessed the possible role of HPyV7 in human thymic epithelial tumors and other thymic tissues.

\section{Materials and methods}

\section{Patients and Tissues}

Formalin-fixed and paraffin-embedded (FFPE) resection specimens were included in this study. All thymomas and two thymic carcinomas ( 19 female and 18 males; mean age 58.3 years; range 34-82 years), and 20 fetal gestational thymic tis-sues from fetus autopsies had been obtained for diagnostic and therapeutic reasons. So had 20 thymi with follicular hyperplasia, 19 of them from patients with MG (15 females, 5 males, mean age 27.4 years), of which 17 with anti-acetylcholine receptor (AChR) antibodies and 4 receiving 
immunosuppressive therapy (steroids). Twenty-six thymoma patients were known with a history of MG, of which 23 were anti-AChR antibodies positive and 3 negatives. Thirteen of the $26 \mathrm{MG}$-positive thymoma patients received immunosuppressive (steroids) therapy. Clinicopathological data of thymoma and hyperplastic thymi patients are summarized in Tables 1 and 2. All specimens were obtained from the Maastricht Pathology Tissue Collection. All use of tissue and patient data was in agreement with the Dutch Code of Conduct for Observational Research with Personal Data (2004) and Tissue (2001, www.fmwv.nl).

\section{HPyV7 Detection by DNA PCR}

Genomic DNA was isolated from whole FFPE tis-sue sections using a DNA Isolation Kit (Qiagen, Hilden, Germany). DNA quality and integrity were first assessed by specimen control size ladder (Tables 1 and 2 ) as described ${ }^{19}$; we excluded any sample where it was inadequate. HPyV7 DNA PCR was performed as described previously, using oligonucleotides targeting the small T antigen (181 base pairs) and the large $T$ antigen (LTAg) (112 base pairs). ${ }^{17,20}$

\section{Detection of HPYV7 by Fluorescence In Situ Hybridization (FISH)}

The HPyV7 full-length probe was obtained from Addgene, Cambridge, MA, and linearized. FISH was per-formed on 3- $\mu$ m-thick FFPE sections according to Hopman et al. with modifications. ${ }^{21}$ In brief, deparaffinized sections were incubated with $0.2 \mathrm{M} \mathrm{HCl}$ for $20 \mathrm{~min}$ (and washed in $\mathrm{dH}_{2} \mathrm{O}$ and $2 \times \mathrm{SSC}$ ), and then with $1 \mathrm{M} \mathrm{NaSCN}$ for $30 \mathrm{~min}$ at $80^{\circ} \mathrm{C}$. After further washing, sections were digested with $1 \mathrm{mg} / \mathrm{ml}$ pepsin (2500-3500 U/mg; Sigma Chemical, St. Louis, MO), pH 2. To test HPyV7-probe specificity, sections were first treated with $0.2 \mathrm{~g} / 100 \mathrm{ml}$ pepsin (Sigma) in $0.01 \mathrm{M} \mathrm{HCl}$ at $37^{\circ} \mathrm{C}$ for $10 \mathrm{~min}$ and then with DNase I (Qiagen) for $30 \mathrm{~min}$ at $37^{\circ} \mathrm{C}$ with $5.7 \mathrm{U}$ in RDD buffer (Qiagen), before cooling on ice, washing twice in $2 \times \mathrm{SSC}$, and post fixing in $4 \%$ form-aldehyde. After washing in $2 \times \mathrm{SSC}$ and rinsing in $\mathrm{dH} 2 \mathrm{O}$, the sections were dehydrated in an ascending ethanol series. The biotin-labeled HPyV7 probe was added under the coverslip at a concentration of $10 \mathrm{ng} / \mathrm{\mu l}$ in LCI/WCP buffer (Vysis, Abott, IL) together with 50x excess human COT-1 DNA (Vysis) and 50x tRNA from S. cerevisiae (Sigma). Denaturation of the probe and the target DNA was carried out simultaneously for $5 \mathrm{~min}$ at $80^{\circ} \mathrm{C}$ before hybridization overnight at $37^{\circ} \mathrm{C}$ in a humid chamber (Thermobrite, Abbott, IL). Unhybridized probe was stringently washed away from the preparations in $2 \times \mathrm{SSC}, \mathrm{pH} 7.0$ at $70^{\circ} \mathrm{C}$ for $2 \mathrm{~min}$. The biotin (Bio)labeled probe was detected with sequential incubations with fluorescein isothiocyanate (FITC)-conjugated avidin (1:500; Vector, Brunswig Chemie, Amsterdam, The Netherlands), biotin-conjugated goat anti-avidin (1:100; Vector), and FITC-conjugated avidin 1:500, all for $30 \mathrm{~min}$ at $37^{\circ} \mathrm{C}$ and diluted in Boehringer Blocking reagent (Roche). Finally, the slides were dehydrated in an ascending ethanol series and mounted in 0.2 $\mu \mathrm{g} / \mathrm{ml}$ DAPI Vectashield (Vector Laboratories, CA). HPyV7 FISH signals were detected 
using a DM 5000 B fluorescence microscope (Leica, Wetzlar, Germany) equipped with DAPI, TR (Texas red) and FITC filters. Images were recorded with a Leica DC 300 Fx camera (Leica). FISH fluorescence intensity, signal numbers, and sizes for strong and weak nuclear FISH signals were evaluated independently by five investigators (D.R., M.K., E.J.S., A.H., A.z.H.) according to the criteria in Hafkamp et al.22 After DNAse pretreatment (see above) of the slides of HPyV7 DNA positive cases, as assessed by PCR and sequencing, no specific nuclear HPyV7 hybridization signals were seen. In addition, specificity of the HPyV7 probe was assessed by the omission of the HPyV7 probe revealing no specific FISH hybridization signals in HPyV7 DNA positive skin and thymic tissues. Cross-hybridization with MCPyV was excluded by performing HPyV7 FISH on the MCPyV-positive MKL1 cell line, which did not show any specific hybridization signals (Figure. S1). ${ }^{13}$

\section{Immunohistochemistry (IHC) and Double Staining}

The following antibodies and dilutions were used: anti-Pancytokeratin AE1/3 (DAKO; Glostrup, Denmark; "Ready to use Antibody"); monoclonal antibody 2T10 against LT-Ag of HPyV7 was provided by C. Buck, NCl, Bethesda, and used at 1:100 with the EnVision FLEX $^{\mathrm{TM}}$ visualization Kit K8008 DAKO according to standard protocols. When FISH was followed by IHC, the protocols were adapted slightly.

\section{Results}

\section{HPyV7 Detection in Thymic Epithelial Tumors by DNA PCR and FISH}

Screening of diverse human cancers for the presence of novel polyomaviruses revealed that HPyV7 was frequently present in human thymomas but not HPyV6. (Figure. 1). Twenty (54\%) of the 37 thymomas tested positive for HPyV7-DNA by PCR (Table 1). All PCR products were sequenced and con-firmed the presence of HPYV7, with only minor nucleotide differences between them. One of the two thymic carcinomas was HPyV7DNA positive and the other negative. 


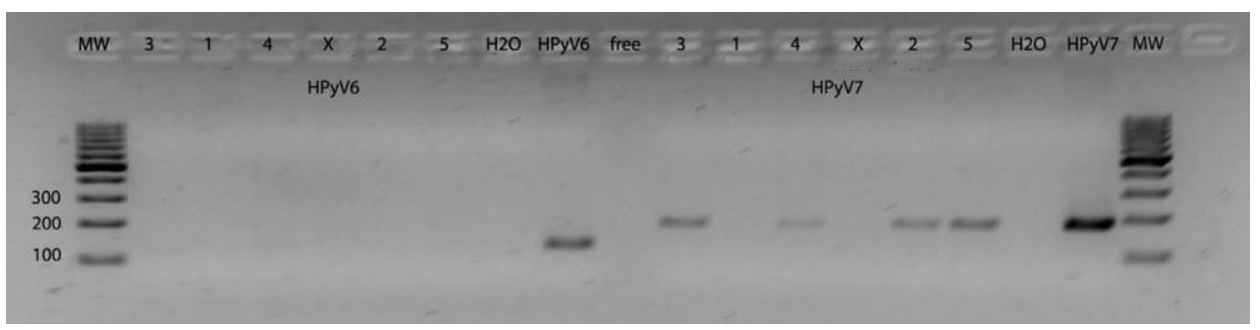

FIGURE 1. PCR-DNA of HPyV6 (left panel) and HPyV7 (right panel) in human epithelial thymic tumors $(3,1,4,2,5)$ and non-neoplastic mediastinal fatty tissue $(X)$ using a plasmid containing human polyomavirus 6 (123 base pair) or 7 (181 base pair). No amplification products were found in HPyV6 PCR whereas specific PCR products were found for HPyV7. PCR, polymerase chain reaction; HPyV7, human polyomavirus 7; $\mathrm{H}_{2} \mathrm{O}$, water control; pos, positive control; free, free space, MW, molecular weight marker.

By FISH, HPyV7-specific nuclear hybridization signals were found in 23 thymomas (62.2\%) (Figure. 2; summarized in Table 1). In these, 15 thymomas with strong to very strong specific nuclear hybridization signals and eight revealed weak positivity. In the thymomas with strong nuclear hybridization signals, almost all neoplastic cells were HPyV7-positive. They were more heterogeneous in the eight with weaker signals. HPyV7-FISH and antipancytokeratine immunofluorescence double labeling confirmed that the specific nuclear hybridization was mostly restricted to epithelial cells (Figure. 2); only in a few tumors was it also found in rare lymphocytes. HPyV7 did not correlate with any World Health Organization thymoma subtype (Table 1).

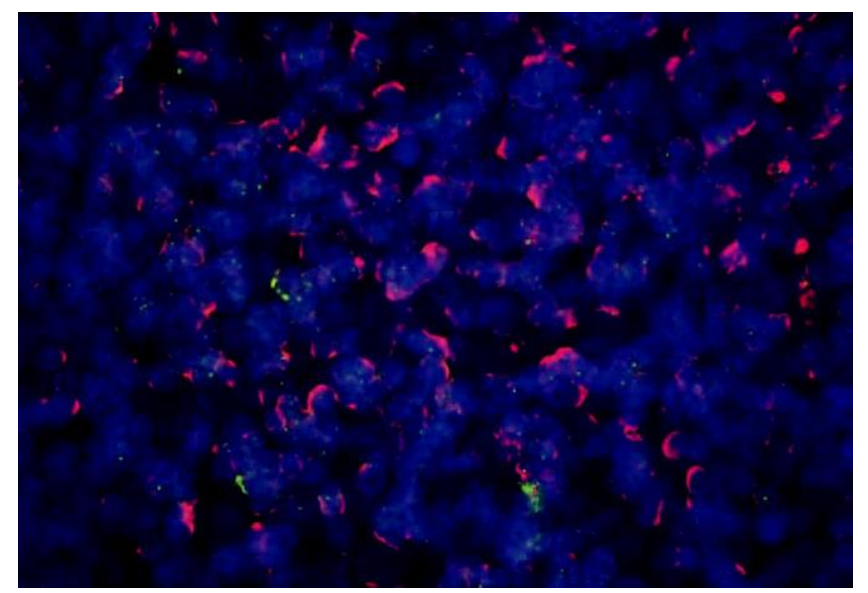

FIGURE 2. Overlay of HPYV7 FISH (green dots) and pan-cytokeratin AE1/AE3 immunofluorescence (red membrane staining) and DAPI staining of the nuclei (blue) of thymoma 1-22 (Table 1). Specific detection of nuclear HPyV7 DNA by FISH (green dots) in epithelial cells of a thymoma as indicated by the red membrane staining. HPyV7, human polyomavirus 7; FISH, fluorescence in situ hybridization. 
Detection of Human Polyomavirus 7 in Human Thymic Epithelial Tumors

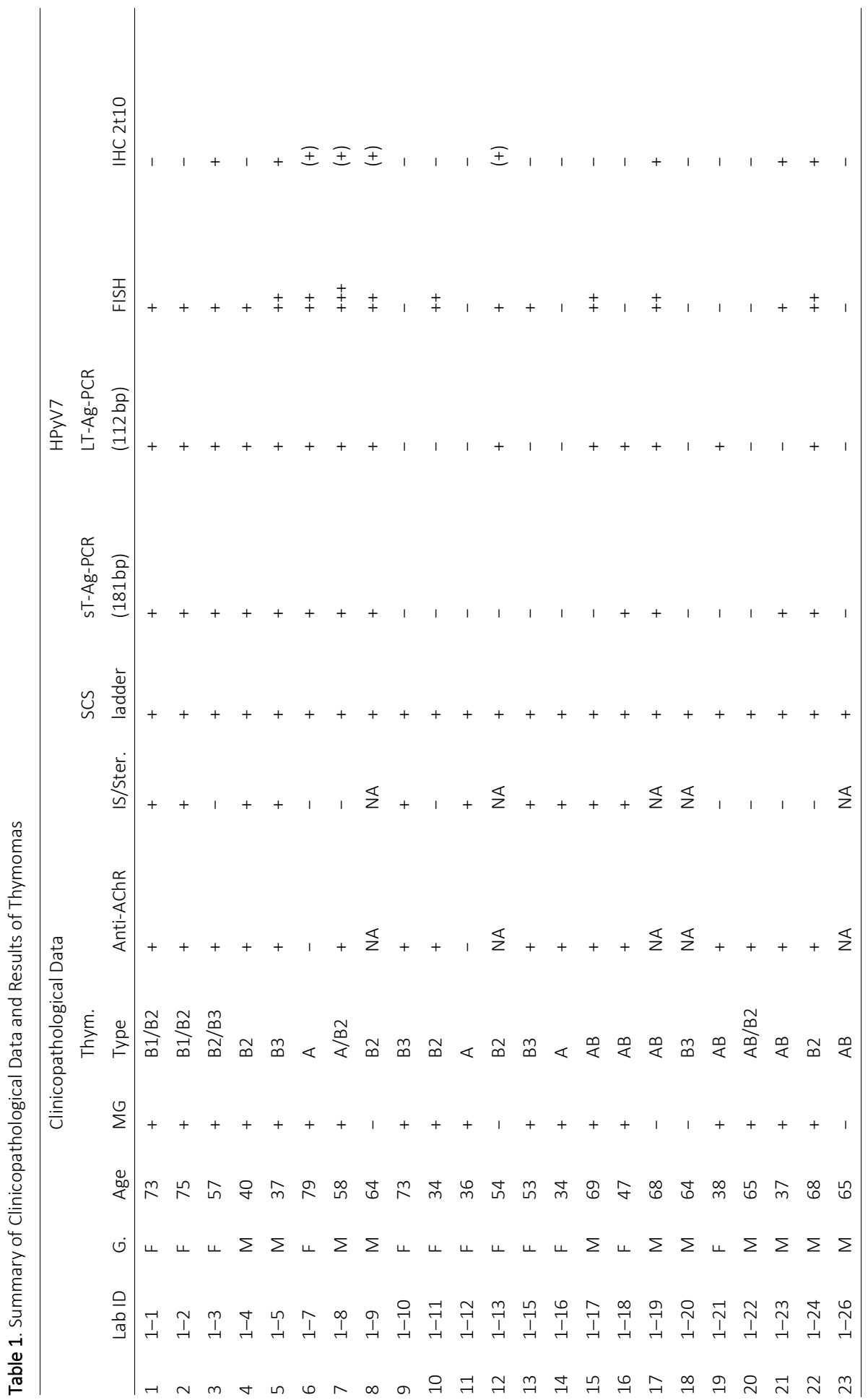




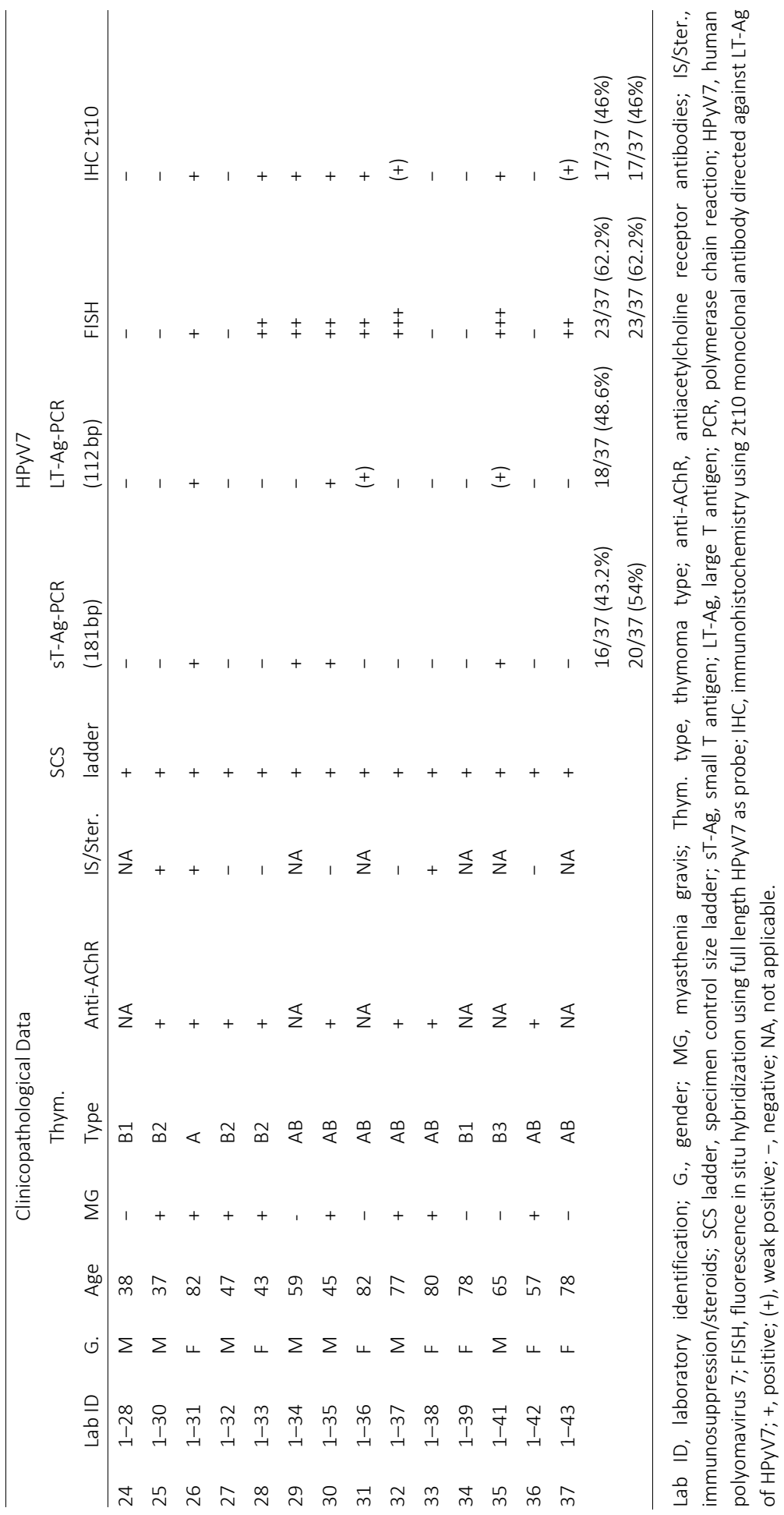


Detection of Human Polyomavirus 7 in Human Thymic Epithelial Tumors

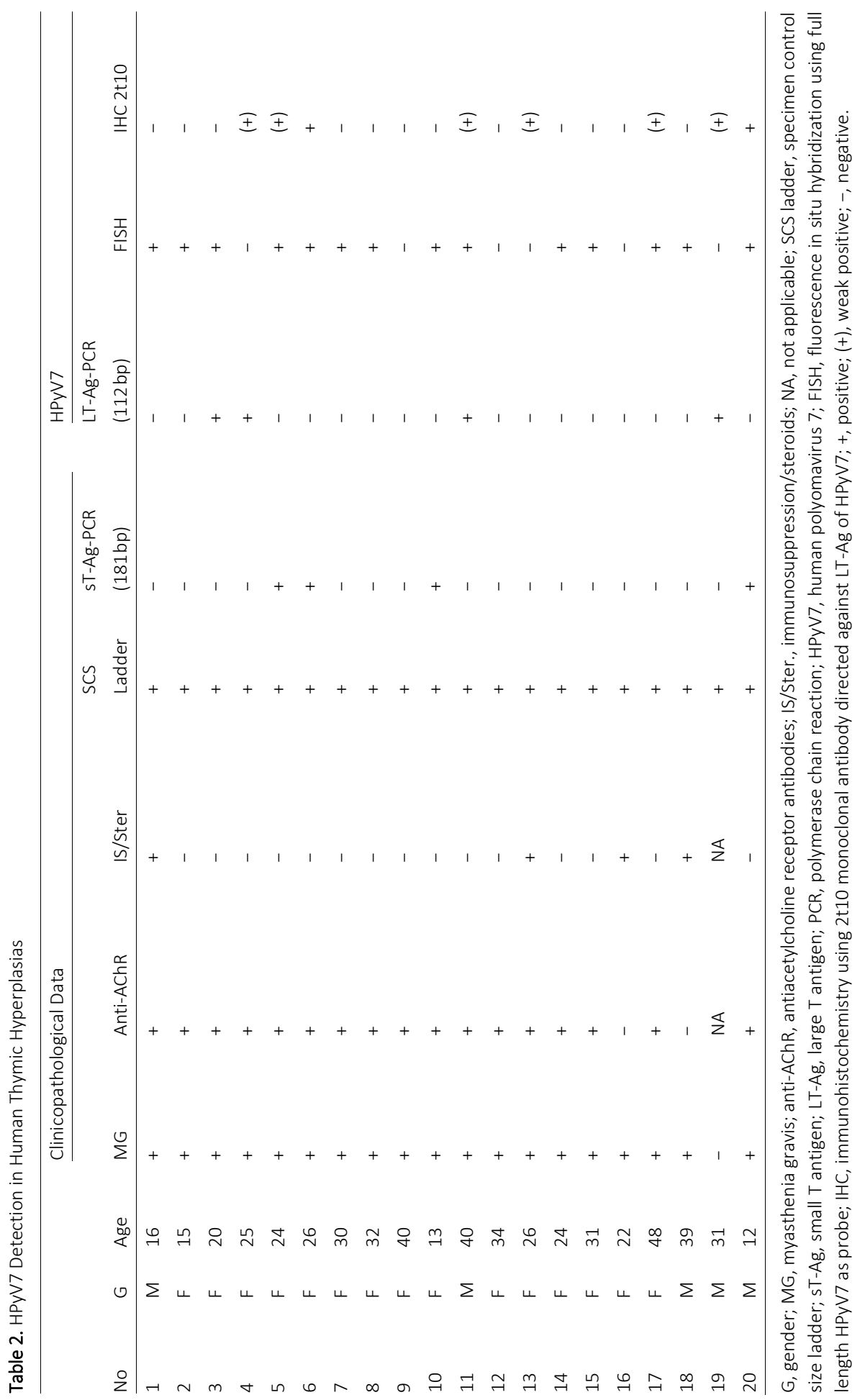




\section{Detection of HPYV7 in Thymic Follicular Hyperplasia DNA PCR and FISH}

HPyV7-DNA was detected in 40\% $(n=8)$ of the hyper-plastic thymi. By HPyV7-FISH, the proportion of HPyV7-positive cases reached $65 \%(n=13)$. Importantly, specific nuclear HPyV7-hybridization signals were mostly restricted to scattered follicular B-cells, which possibly explain the different results of PCR and FISH. In six of these 20 hyperplastic thymi, IHC revealed mostly weak nuclear expression of the LT-Ag in some lymphoid cells in the follicles (Figure. $3 C$ and $D$ )

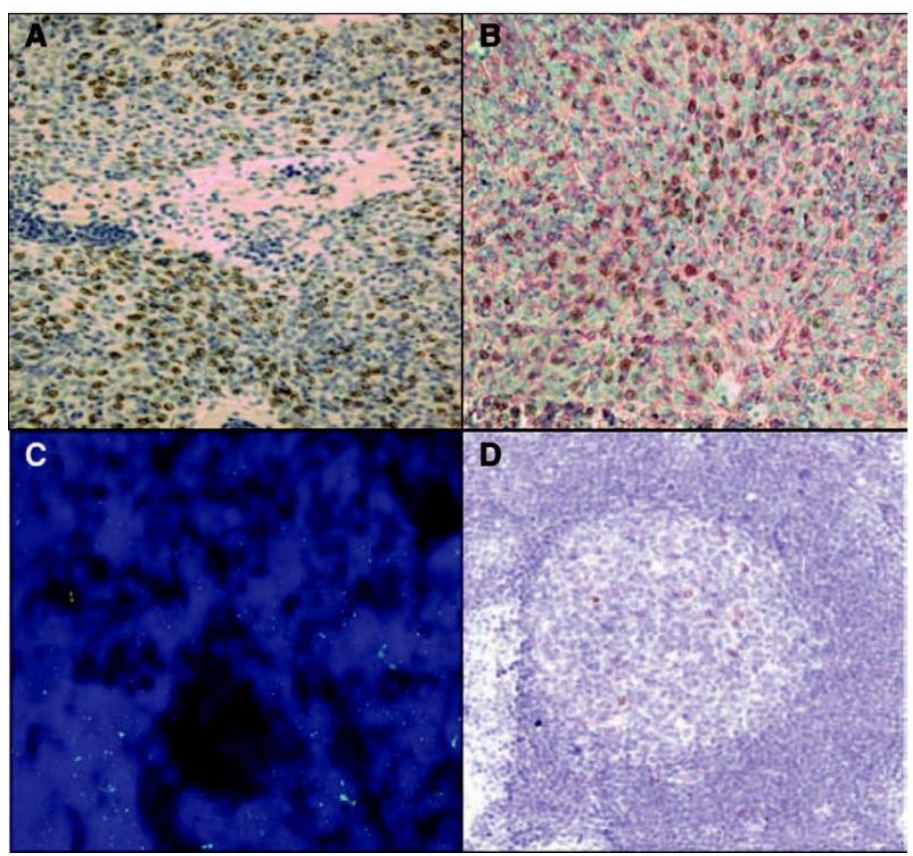

FIGURE 3. A, Specific nuclear expression of the HPyV7 LT-Ag (dark brown) in thymoma 1-3 (Table 1) as assessed by immunohistochemistry. Epithelial cells are positive whereas the lymphoid cells do not show HPyV7 LT-Ag expression. B, Immunohistochemical double staining technique confirms the expression of the HPyV7 LTAg in the nuclei (dark brown) of thymic epithelial cells as identified by the red membrane staining with the pancytokeratine antibody AE1/AE3 in thymoma 1-3 (Table 1). C, Representative result of the HPyV7 FISH in a follicular center of a hyperplastic thymus. The green nuclear dots represent the HPyV7 signals obtained by the hybridization with HPyV7 probe. D, Specific nuclear expression of the HPyV7 LT-Ag (dark brown) in a hyperplastic thymus Expression of HPyV7 LT-Ag is mostly restricted to follicular lymphocytes. HPyV7, human polyomavirus 7; LT-Ag, large T antigen; FISH, fluorescence in situ hybridization.

\section{Association of HPyV7 and MG}

Of the 26 patients with HPyV7-positive thymomas, 19 were known to have MG. Of the 11 non-MG thymomas, seven were HPyV7-positive and four were HPyV7-negative (Table 1). The only non-MG-hyperplastic thymus was HPyV7-positive. 


\section{HPyV 7 Is Not Detected in Fetal Thymus}

Using HPYV7 DNA PCR, none of the fetal thymi, which were also tested for sufficient DNA quality and integrity, tested positive for HPyV7.

\section{Discussion}

With sophisticated new detection techniques, the number of novel human polyomaviruses has increased in the past 6 years. ${ }^{23}$ However, of the 12 known human polyomaviruses, currently, only the MCPyV has been shown to be associated with a human cancer, that is, the MCC. Viral integration, tumor-specific viral mutations within the LT-Ag of MCPyV, and consistent epidemiology of MCPyV with MCC have led to the classification of MCPyV as a class $2 \mathrm{~A}$ carcinogen by the International Agency for Research on Cancer. ${ }^{13-16,24}$

Here, we systematically assessed the presence of HPyV7 in human thymic epithelial tumors by diverse molecular techniques. ${ }^{17}$ Focusing on different parts of the HPyV7 genome, we found HPyV7-DNA in 54\% of the 37 thymomas. At the single cell level, use of HPyV7-FISH demonstrated specific nuclear hybridization signals within the epithelial cells in $62.2 \%$ of the thymomas and only occasionally in lymphocytes. The discrepancies between the PCR and FISH results most likely reflect the varying proportions of positive cells in different tumors. Interestingly, however, thymomas 1-37 and 1-43 (Table 1) gave strong hybridization signals in HPyV7 FISH plus weak IHC labeling for its LTAg despite negativity by HPyV7 PCR. Because we excluded technical reasons as far as possible, and also the presence of other known human polyomaviruses, these findings might hint at the presence of an as yet unidentified but closely related polyomavirus.

Our double labeling clearly showed that the great majority of the cells positive for viral DNA or protein antigens were epithelial rather than lymphoid. Thus, the expression of the HPYV7-LTAg in thymomas may hint at a role for HPyV7 in thymomagenesis. Although many other polyoma viral LT-Ag can act as oncogenes, no information is yet available about the oncogenic capacity of HPyV7. Notably, its LTAg was expressed quite strongly in some of the epithelial thymic tumors, especially compared with the variable numbers of HPyV7 LT-Ag lymphoid cells in thymic follicles (Figure. 3D).

In the hyperplastic thymi, HPyV7 DNA was detected by PCR in $40 \%$ and by FISH in $65 \%$. The discrepancy can readily be explained by the number of cells detected by HPYV7-FISH, which varied over a wide range. By using HPyV7 FISH and an anti-HPyV7 LT-Ag monoclonal anti-body, HPyV7-positivity was found to be largely restricted to follicular lymphoid rather than epithelial cells. That is in line with the known B lymphotropism of some human polyoma-viruses.12,25,26 This finding is interesting because if HPyV7 remains latently present in follicular B-cells, it could mean that it might be interesting to 
test also B-cell non-Hodgkin lymphomas for the presence of HPyV7. In addition, it may contribute to immunological alterations, which might initiate or perpetuate immunological diseases such as MG as has recently been speculated for the oncogenic $\gamma$ herpesvirus Epstein-Barr (EBV).27 However, data on the finding of EBV in MG thymus are quite controversial, ranging between very high prevalence to almost not present.28,29 Although surprising that a highly reproducible standard routine testing for the presence of EBV (e.g., EBV-encoded RNAs, RNA in situ hybridization) in a histopathological lymphoma diagnostic setting fails the extent of reproducibility in the setting of MG thymus, it seems that further conclusive studies are needed to assess the role of EBV in MG thymi. The interesting recent finding of poliovirus in a subset of MG thymi needs to be independently confirmed. 30

The fact that we did not find any HPyV7-positivity in gestational fetal thymic tissues reveals that HPyV7 infection occurs in the postnatal period and also indirectly leans support to a possible role for HPyV7 in human thymomagenesis in the context of the quite frequent finding within the epithelial cells of human thymic epithelial tumors.

In conclusion, this study is the first to demonstrate the presence and association of HPyV7 in thymic epithelial tumors by diverse molecular techniques. Our failure to detect any signs of HPyV7 in fetal thymic tissues suggests that HPyV7 reaches the thymus postnatal or later in life, which is in good agreement with the recent study on HPyV7 age related seroprevalence. ${ }^{18}$ Its contrasting 40\%to- $60 \%$ prevalence in thymomas also hints at a possible role for HPyV7 in their initiation, but requires independent confirmation in larger series.

Further studies would also be needed to assess the oncogenic potential of HPyV7, for example, viral integration, mutational analyses of the LT-Ag, and in vitro trans-formation. Although HPyV7 is present in the majority of MG-associated thymomas, the numbers of cases investigated in this study do not allow a conclusion on a possible role of HPyV7 in MG. 


\section{References}

1. Travis WD, Brambilla E, Müller-Hermelink HK, Harris CC (Eds.). Introduction in World Health Organization Classification of Tumours. Pathology and Genetics of Tumours of the Lung, Thymus and Heart. Lyon, France: IARC Press, 2004. Pp. 145-151.

2. Ströbel $P$, Hohenberger $P$, Marx A. Thymoma and thymic carci-noma: molecular pathology and targeted therapy. J Thorac Oncol 2010;5:S286-S290.

3. McGuire LJ, Huang DP, Teoh R, Arnold M, Wong K, Lee JC. Epstein-Barr virus genome in thymoma and thymic lymphoid hyperplasia. Am J Pathol 1988;131:385-390.

4. Borisch B, Kirchner T, Marx A, Müller-Hermelink HK. Absence of the Epstein-Barr virus genome in the normal thymus, thymic epithelial tumors, thymic lymphoid hyperplasia in a European population. Virchows Arch B Cell Pathol Incl Mol Pathol 1990;59:359-365.

5. Inghirami G, Chilosi M, Knowles DM. Western thymomas lack Epstein-Barr virus by Southern blotting analysis and by polymerase chain reac-tion. Am J Pathol 1990;136:1429-1436.

6. Engel PJ. Absence of latent Epstein-Barr virus in thymic epithelial tumors as demonstrated by Epstein-Barrencoded RNA(EBER) in situ hybridiza-tion. APMIS 2000;108:393-397.

7. Chen PC, Pan CC, Yang AH, Wang LS, Chiang H. Detection of Epstein-Barr virus genome within thymic epithelial tumours in Taiwanese patients by nested PCR, PCR in situ hybridization, and RNA in situ hybridization. J Pathol 2002;197:684-688.

8. Wirth JJ, Fluck MM. Immunological elimination of infected cells as the candidate mechanism for tumor protection in polyomavirus-infected mice. J Virol 1991;65:6985-6988.

9. Sanjuan N, Porrás A, Otero J, Perazzo S. Expression of major capsid pro-tein VP-1 in the absence of viral particles in thymomas induced by murine polyomavirus. J Virol 2001;75:2891-2899.

10. Van Ghelue M, Khan MT, Ehlers B, Moens U. Genome analysis of the new human polyomaviruses. Rev Med Virol 2012;22:354-377.

11. Siebrasse EA, Reyes A, Lim ES, et al. Identification of MW polyomavi-rus, a novel polyomavirus in human stool. J Virol 2012;86:10321-10326.

12. DeCaprio JA, Garcea RL. A cornucopia of human polyomaviruses. Nat Rev Microbiol 2013;11:264-276.

13. Feng $H$, Shuda $M$, Chang $Y$, Moore PS. Clonal integration of a polyoma-virus in human Merkel cell carcinoma. Science 2008;319:1096-1100.

14. Kassem A, Schöpflin A, Diaz C, et al. Frequent detection of Merkel cell polyomavirus in human Merkel cell carcinomas and identification of a unique deletion in the VP1 gene. Cancer Res 2008;68:5009-5013.

15. Becker JC, Houben R, Ugurel S, Trefzer U, Pföhler C, Schrama D. MC polyomavirus is frequently present in Merkel cell carcinoma of European patients. J Invest Dermatol 2009;129:248-250.

16. Shuda M, Feng $\mathrm{H}$, Kwun HJ, et al. T antigen mutations are a human tumor-specific signature for Merkel cell polyomavirus. Proc Natl Acad Sci U S A 2008;105:16272-16277.

17. Schowalter RM, Pastrana DV, Pumphrey KA, Moyer AL, Buck CB. Merkel cell polyomavirus and two previously unknown polyomaviruses are chronically shed from human skin. Cell Host Microbe 2010;7:509515.

18. Nicol JT, Robinot R, Carpentier A, et al. Age-specific seroprevalences of merkel cell polyomavirus, human polyomaviruses 6,7 , and 9, and tricho-dysplasia spinulosa-associated polyomavirus. Clin Vaccine Immunol 2013;20:363-368.

19. van Dongen JJ, Langerak AW, Brüggemann $M$, et al. Design and stan-dardization of PCR primers and protocols for detection of clonal immunoglobulin and T-cell receptor gene recombinations in suspect lymphoproliferations: report of the BIOMED-2 Concerted Action BMH4-CT98-3936. Leukemia 2003;17:2257-2317.

20. Duncavage EJ, Pfeifer JD. Human polyomaviruses 6 and 7 are not detect-able in Merkel cell polyomavirusnegative Merkel cell carcinoma. J Cutan Pathol 2011;38:790-796.

21. Hopman AH, Kamps MA, Smedts F, Speel EJ, Herrington CS, Ramaekers FC. HPV in situ hybridization: impact of different protocols on the detec-tion of integrated HPV. Int J Cancer 2005;115:419-428. 


\section{Chapter 3}

22. Hafkamp HC, Manni JJ, Haesevoets A, et al. Marked differences in sur-vival rate between smokers and nonsmokers with HPV 16-associated ton-sillar carcinomas. Int J Cancer 2008;122:2656-2664.

23. Dalianis T. Immunotherapy for polyomaviruses: opportunities and chal-lenges. Immunotherapy 2012;4:617-628

24. Bouvard V, Baan RA, Grosse Y, et al. Carcinogenicity of malaria and of some polyomaviruses. Lancet Oncol 2012;13:339-340.

25. Toracchio S, Foyle A, Sroller V, et al. Lymphotropism of Merkel cell polyoma-virus infection, Nova Scotia, Canada. Emerg Infect Dis 2010;16:1702-1709.

26. Pantulu ND, Pallasch CP, Kurz AK, et al. Detection of a novel truncating Merkel cell polyomavirus large T antigen deletion in chronic lymphocytic leukemia cells. Blood 2010;116:5280-5284.

27. Cavalcante $P$, Serafini B, Rosicarelli B, et al. Epstein-Barr virus per-sistence and reactivation in myasthenia gravis thymus. Ann Neurol 2010;67:726-738.

28. Meyer M, Höls AK, Liersch B, et al. Lack of evidence for Epstein-Barr virus infection in myasthenia gravis thymus. Ann Neurol 2011;70:515-518.

29. Kakalacheva K, Maurer MA, Tackenberg B, Münz C, Willcox N, Lünemann JD. Intrathymic Epstein-Barr virus infection is not a promi-nent feature of myasthenia gravis. Ann Neurol 2011;70:508-514.

30. Cavalcante $\mathrm{P}$, Barberis $\mathrm{M}$, Cannone $\mathrm{M}$, et al. Detection of poliovirus-infected macrophages in thymus of patients with myasthenia gravis.Neurology2010;74:1118-11 


\section{Chapter}

\section{Expression of $\mathrm{pRb}$ and $\mathrm{p} 16 \mathrm{INK} 4$ in human thymic epithelial tumors in relation to the presence of human polyomavirus 7}

Marlies Keijzers, Dorit Rensspiess, Sreedhar Pujari, Myrurgia A. Abdul-Hamid, Monique Hochstenbag, Anne-Marie Dingemans, Anna Kordelia Kurz, Anke Haugg, Jos. G. Maessen, Marc H. De Baets and Axel zur Hausen

Diagnostic Pathology

(2015) 10:201 DOI 10.1186/s13000-015-0418-6

Received: 23 July 2015 Accepted: 1 October 2015

Published online: 04 November 2015 


\section{Abstract}

Background: We have recently reported the presence of the Human polyomavirus 7 (HPyV7) in human thymic epithelial tumors as assessed by diverse molecular techniques. Here we report on the co-expression of $p 16$, retinoblastoma protein ( $p R b)$ and phosphorylated retinoblastoma protein (phospho- $\mathrm{Rb}$ ) in human thymic epithelial tumors in relation to HPyV7.

Methods: PRB, phospho-RB and p16 expression was assessed by immuno-histochemistry in 37 thymomas and 2 thymic carcinomas. 17 thymomas (46\%) and 1 thymic carcinoma (50\%) were recently tested positive for HPyV7. In addition, 20 follicular hyperplasias were tested.

Results: Expression of pRb was observed in 35 thymomas (94.6\%), in 16 thymomas (43.2 $\%)$ the expression was strong. Phospho-Rb was observed in 31 thymomas (83.8 \%). 19 thymomas (51.4\%) showed immunoreactivity for 16 of which 8 thymomas revealed very strong p16 expression. No p16 expression was detected in thymic carcinomas. In addition, no significant correlation between the presence of HPyV7 and pRb-, phospho$\mathrm{Rb}$ - and $\mathrm{p} 16$-expression could be established. No correlation between $\mathrm{pRb}$, phospho-Rb, p16 and WHO staging, Masaoka-Koga staging or the presence of MG was found. All 20 follicular hyperplasias showed expression of $\mathrm{pRb}$ and less expression of phospho- $\mathrm{Rb}$.

Conclusions: Although polyomaviruses have been shown to interact with cell cycle proteins no correlation between the presence of HPyV7 and the expression of pRb, phospho-Rb and p16 in human thymic epithelial tumors was observed. In as much HPyV7 contributes to human thymomagenesis remains to be established. Our data indicate pRb, phospho-Rb and p16 expression are rather unlikely to be involved in HPyV7 related thymomagenesis.

Keywords: Thymic epithelial tumors, Human polyomavirus 7, pRB, p16, Viral tumorigenesis 


\section{Background}

Thymomas are rare tumors arising from thymic epithelial cells. Frequently there is an association with autoimmune diseases, most often (24.5-40 \%) with Myasthenia Gravis (MG) [1]. The aetiology of thymomas is unknown though many studies focus on the role of viruses testing diverse histological subtypes of thymic AKR the polyomavirus strain PTA induces thymomas, $[4,5]$. We have recently reported the presence of the Human Polyomavirus 7 (HPyV7) in a large number of human thymic epithelial tumors by fluorescence in situ hybridization (FISH), immunohistochemistry (IHC) and polymerase chain reaction (PCR). [6]. The human polyomavirus 7 (HPyV7) was recently detected in 2010 from skin samples and prior to our report no other human disease had been associated with the presence of HPyV7 [7].

The human polyomavirus family is currently grow-ing very fast [8-10], however, only the Merkel cell polyomavirus (MCPyV) has yet been identified as a novel human tumor virus in Merkel cell carcinomas (MCC), which is a very aggressive skin cancer of elderly and immune suppressed patients [11]. MCPyV is found in more than $80 \%$ of MCC's and its DNA is clonally integrated in the tumor genomes [11, 12]. In addition, MCPyV harbours tumor specific mutations of the large T antigen (LT-Ag) [13]. MCPyV is sup-posed to induces tumorgenesis via truncated large $T$ antigen (LT-ag) and small T antigen (ST-ag) possibly inhibiting the tumor suppressor protein retinoblastoma ( $\mathrm{RRb}$ ) and protein 53 (p53) [14-16]. It has been demonstrated that the polyomavirus simian virus (SV

interacts through large $T$ antigen in the cell cycle by the binding of pRb and p53 [17]. Recently it has been proposed that the LT-ag from WU polyomavirus, human polyomavirus 6, HPyV7 and Malawi polyoma-virus might interact with p53 and pRb [18, 19]. Hu-man papilloma virus (HPV), another potent small DNA tumor virus is one of the most important viral causes of human cancer, and shares with MCPyV a homolog LXCXE motif in the encoded RB binding site $[13,20]$. Although HPV could not be related to thymomagenesis increased transcript expression of p16 (cyclin-dependent kinase inhibitor 2A) was reported in human thymomas [21]. P16 is frequently used as a surrogate marker for HPV infection in HPV related cervical and oropharyngeal cancers [22]. Of interest, only very limited data are available regarding the possible role of pRB and p16 in human thymomas $[23,24]$. In the present study we aimed to analyse the ex-pression of pRB and p16 in human thymic epithelial tumors in relation to the presence of HPyV7. 


\section{Methods}

\section{Patients and tissue}

Formalin-fixed and paraffin-embedded (FFPE) resection specimens were included as previously described [6]. In total 37 thymomas and 2 thymic carcinomas (19 females and 18 males; mean age 58.3 years; range 34-82 years), 20 follicular hyperplasias ( 15 females, 5 males, and mean age 27.4 years) of which 19 were diagnosed with MG, were included in this study. Thymomas were classified according to the world health organization (WHO) classification in thymoma type A, type AB, type B1, B2, B3 or thymic carcinoma [25]. The Masaoka-Koga classification was used to define the invasiveness of a thymoma [26]. Clinicopathological data of thymoma and thymic carcinoma patients are summarized in Tables 1 and 2. All specimens were obtained from the Maastricht Pathology Tissue Collection (MPTC). All use of tissues and patient data was in agreement with the Dutch Code of Conduct for Observational Research with Personal Data (2004) and Tissue (2001, www.fmwv.nl).

\section{Immunohistochemistry}

$\mathrm{PRb}$ and phosphorylated $\mathrm{Rb}$ (phospho-Rb) expression was detected by using two monoclonal Retinoblastoma anti-bodies: pRb (a.a. 332-344), clone G3-245, Pharmingen, dilution 1:300 and phospho-Rb, clone D20B12, dilution 1:100. P16 expression was performed with a monoclonal antibody (clone JC8, dilution 1:400) (Santa Cruz). Secondary antibody detection and visualization were done with the EnVision FLEX ${ }^{\text {TM }}$ Kit K8008 (DAKO) or K5005 (Dako) according to standard protocols. Expression levels were assessed and scored by three experienced investigators ( $\mathrm{AzH}, \mathrm{MAH}, \mathrm{DR}$ ). The results of the HPyV7 LT-Ag expression using the $2 \mathrm{t} 10$ antibody have been described previously [6]. In the epithelial cells of 17 thymomas (46\%) marked LT-Ag expression was found. The expression of LT-Ag was in good agreement with earlier performed HPyV7-DNA PCR and/or the HPyV7-FISH [7].

\section{Statistics}

Statistical analysis was performed with SPSS 20.0 statistical software (SPSS Inc., Chicago, IL, USA). Dichotomous variables are expressed as absolute numbers and percentages (\%) and were compared using the chi-square test or Fisher's exact test as appropriate. The Spearman's rank correlation was used in non-parametric data to study the associations between different variables. Statistical significance was considered with the probability value of $P<0.05$. 
Expression of $\mathrm{pRb}$ and $\mathrm{p} 16 \mathrm{NNK} 4$ in human thymic epithelial tumors

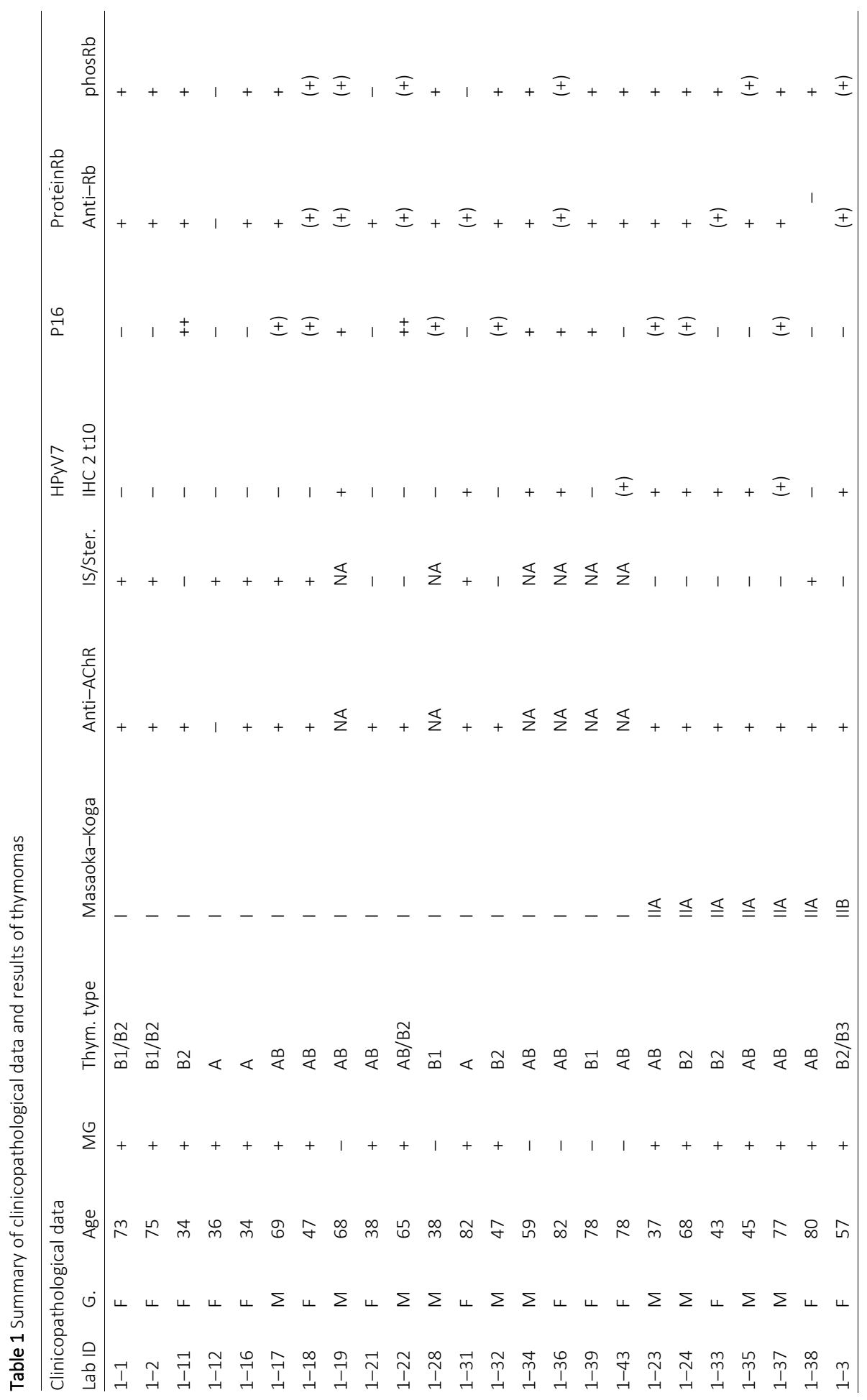




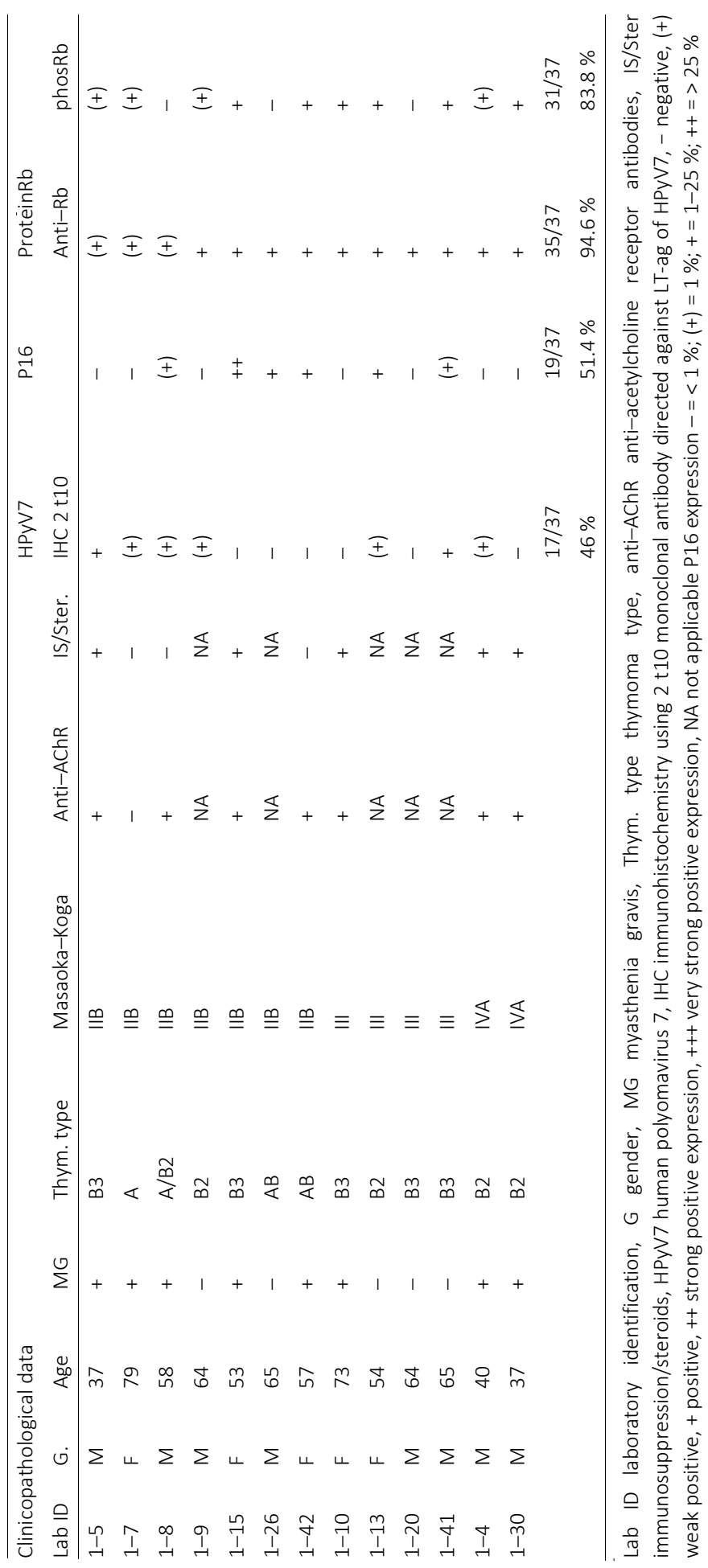


Table 2 Summary of clinicopathological data and results of thymic carcinomas

\begin{tabular}{|c|c|c|c|c|c|c|c|c|c|c|}
\hline \multicolumn{5}{|c|}{$\begin{array}{l}\text { Clinicopathological } \\
\text { data }\end{array}$} & \multirow[b]{2}{*}{ Anti-AChR } & \multicolumn{2}{|r|}{ HPyV7 } & \multirow[t]{2}{*}{ P16 } & \multicolumn{2}{|c|}{ ProteinRb } \\
\hline Lab ID G. & Age & MG & Thym. type & $\begin{array}{l}\text { Masaoka- } \\
\text { Koga }\end{array}$ & & IS/Ste & r.IHC 2 t10 & & Anti-Rb & phosRb \\
\hline $1-6 \quad \mathrm{M}$ & 60 & - & C & III & N/A & $\mathrm{N} / \mathrm{A}$ & $(+)$ & - & + & + \\
\hline $1-26 \mathrm{~F}$ & 67 & - & C & IVB & N/A & N/A & - & - & + & + \\
\hline
\end{tabular}

C thymic carcinoma, G gender, MG myasthenia gravis, anti-AChR anti-acetylcholine receptor antibodies, IS/Ster immunosuppression/steroids, NA not applicable, HPyV7 human polyomavirus 7, IHC immunohistochemistry using 2 t10 monoclonal antibody directed against LT-ag of HPyV7, - negative, $(+)$ weak positive, + positive, ++ strong positive expression

\section{Ethical approval}

All specimens were collected at the Department of Path-ology of the Maastricht University Medical Centre, for the Maastricht Pathology Tissue Collection, which includes ethical approval. All use of tissue and patient data was in agreement with the Dutch Code of Conduct for Observational Research with Personal Data (2004) and Tissue (2001, www.fmwv.nl).

\section{Results}

Correlation between $p R b$ and phosphorylated $R b$ expression in human thymomas and thymic carcinomas and HPyV7

Thirty-five thymomas (94.6\%) showed specific expression of pRb within the neoplastic epithelial thymic cells (Figure. 1d). Phospho-Rb was observed in 31 thymomas (83.8 \%) within the same cell compartment as pRb (Figure. 1c). No correlation between phospopRb expression and presence of HPyV7 could be established. In addition, no correlation was observed between the ex-pression of $\mathrm{pRb}$ or phospho-Rb and WHO staging, Masaoka-Koga staging or the presence of MG.

\section{Correlation between HPyV7 and $p 16$ expression in human thymomas and thymic carcinomas}

Nuclear and cytoplasmic p16 expression [27] was detected in 19 thymomas (51.4 \%) mainly within the neoplastic epithelial cells but also in dendritic cells as had been described [28]. Both thymic carcinomas did not reveal any p16 expression. No correlation between the immunoreactivity of $\mathrm{p} 16$ and WHO staging, Masaoka-Koga staging or the presence of MG was established. Of the 17 patients positive for large LT-Ag, 9 patients (52.9\%) showed expression of p16. However, p16 was also detected in 10 patients (50 
\%) negative for LT-Ag (Table 3). Three patients (8.1\%) showed very strong ex-pression of p16 (++) (Figure. 1b). No differences regarding p16 expression levels were observed between LT-Ag positive and negative thymomas. Therefore, the presence of HPyV7 was not associated with p16 expression.

Table 3 Absence of a correlation between P16 and HPyV7 in early and late stage thymoma and thymic carcinoma

\begin{tabular}{|c|c|c|c|c|}
\hline \multicolumn{5}{|l|}{ HPyV7 IHC 2 t10 } \\
\hline & \multicolumn{2}{|c|}{ Masaoka-Koga I or II } & \multicolumn{2}{|c|}{ Masaoka-Koga III or IV } \\
\hline & - & + & - & + \\
\hline \multicolumn{5}{|l|}{ P16 } \\
\hline- & 6 & 8 & 5 & 1 \\
\hline+ & 10 & 7 & 0 & 2 \\
\hline \multirow[t]{2}{*}{ Double positive } & & $15 / 31$ & & $2 / 8$ \\
\hline & & $48.4 \%$ & & $25.0 \%$ \\
\hline
\end{tabular}

\section{Follicular hyperplasia}

$\mathrm{PRb}$ was detected in all 20 follicular hyperplasias in the lymphocytes. Phospho-Rb was also expressed in the lymphocytes in all follicular hyperplasias however, with a much lower intensity.

\section{Discussion}

The presence of HPyV7 and the expression of the viral LT-ag were detected in the epithelial cells of human thymic epithelial tumors by PCR, FISH and IHC [6]. Yet, no information concerning the oncogenic capacity of HPyV7 is available. Of the 12 known human polyomaviruses only MCPyV has proven oncogenic capacity [11]. Expression of p16 has been detected in human thymic epithelial tumors on the transcriptional and translational level $[21,23,24]$. Since expression of $\mathrm{p} 16$ has been proposed as a potential surrogate marker for the presence and involvement of tumor vi-ruses e.g., HPV, we investigated in as much p16 ex-pression in human thymic epithelial tumors correlate with the presence of HPyV7 or expression of its LT-Ag. However, we detected no correlation between the ex-pression of LT-Ag and p16 in human thymic epithelial tumors. Next, we investigated the co-expression of $\mathrm{pRb} /$ phospho-Rb and LT-Ag because $\mathrm{pRb}$ is a major $\mathrm{G} 1$ checkpoint, which blocks S-phase entry and cell growth. However, no correlation between the immunoreactivty of pRB and/or phospho-Rb and LT-Ag was observed.

Interestingly, we did not detect a specific pattern of p16 or pRB expression in relation to the invasive-ness of thymomas. In our study 17/31 (54.8\%) of Masaoka-Koga Stage I or II and 2/8 (25 \%) of Masaoka-Koga stage III or IV thymic epithelial tumors were double positive for P16 and pRb. This is in contrast with Hirabayashi et al. who reported that 
inactivation of p16 or RB could play a role in the progression of thymomas [23]. These differences are most likely a result of a distinct classification of non-invasive and invasive thymomas e.g., Masaoka stage II was counted as non-invasive in our study because of the little difference in overall survival be-tween stage I and II [29]. More recently, Omatsu et al. showed that increasing malignancy is molecularly paralleled by a stepwise increase of p16 expression

However, the difference within expression of p16 was only shown between thymic carcinomas and thymomas, without differences in expression level within thymomas. In our series only two thymic carcinomas were included and they were both negative for p16 expression. Interestingly, there were 3 patients (8.1\%) with strong immunoreactivity of p16 (++), none of these patients showed expression of LT-Ag of HPyV7. As HPV infection has been ruled out as a possible cause for this $\mathrm{p} 16$ overexpression

These findings might suggest a role in virology. Diverse human viruses including Poliovirus and oncogenic $y$-herpesvirus Epstein Barr Virus have been detected in human thymic epithelial tumors $[1,2]$ on the search for the role of viruses in the pathogenesis of MG. Yet, these results need to be confirmed in a larger number of thymic epithelial tumors

\section{Conclusions}

In conclusion, in this study we found no correlation be-tween the presence of HPyV7 and $\mathrm{pRb}$, phospho-Rb and $\mathrm{p} 16$ in human thymic epithelial tumors.

\section{Consent}

All specimens were obtained from the Maastricht Path-ology Tissue Collection. All use of tissue and patient data was in agreement with the Dutch Code of Conduct for Observational Research with Personal Data (2004) and Tissue (2001, www.fmwv.nl), which includes informed patient consent.

\section{Abbreviations}

FISH: Fluorescence in situ hybridization; HPV: Human Papilloma Virus; HPyV7: Human Polyomavirus 7; IHC: Immunohistochemistry; LT-Ag: Large T antigen; MCPyV: Merkelcel Polyoma virus; MG: Myasthenia gravis;

PCR: Polymerase chain reaction; Phospho- Rb: Phosphorylated

Retinoblastoma; pRb: Protein Retinoblastoma; STag: Small T antigen;

WHO: World Health Organization. 


\section{Competing interests}

The authors declare that they have no competing interests.

\section{Authors' contributions}

MK and DR participated in the design of the study, carried out the experiments and wrote the manuscript, SP carried out experiments, $\mathrm{MAH}$ and $\mathrm{AzH}$ reviewed the histopathology and immunohistochemistry. $\mathrm{MH}, \mathrm{AMD}, \mathrm{AK}, \mathrm{AH}, \mathrm{JM}$ contributed essential materials and helped to draft the manuscript. MDB and $\mathrm{AzH}$ are the principal investigators and designed and supervised the study and helped writing the manuscript. All authors read and approved the final manuscript.

\section{Acknowledgements}

All substantial contributions to this study are mentioned in the author's contributions. All authors are employees of the Maastricht University Medical Centre, Maastricht, The Netherlands. Extramural funding: not applicable.

\section{Author details}

${ }^{1}$ Department of Cardiothoracic Surgery, Maastricht University Medical Centre, Maastricht, The Netherlands.

${ }^{2}$ Department of Pulmonology, Maastricht University Medical Centre, Maastricht, The Netherlands.

${ }^{3}$ Department of Pathology, Maastricht University Medical Centre, P. Debyelaan 25, P.O. Box 5800, 6202 AZ Maastricht, The Netherlands.

${ }^{4} \mathrm{GROW}$-School for Oncology and Developmental Biology, Maastricht University Medical Centre, Maastricht, The Netherlands.

${ }^{5}$ Department of Internal Medicine IV, University Hospital Aachen, Aachen, Germany.

${ }^{6}$ Department of Neuro-Science, Maastricht University, School of Mental Health and Neuroscience (MHeNS), Maastricht, The Netherlands.

Received: 23 July 2015 Accepted: 1 October 2015

Published online: 04 November 2015 


\section{References}

1. Cavalcante $\mathrm{P}$, Barberis M, Cannone M, Baggi F, Antozzi C, Maggi L, et al. Detection of poliovirus-infected macrophages in thymus of patients with myasthenia gravis. Neurology. 2010;74(14):1118-26. doi:10.1212/ WNL.0b013e3181d7d884.

2. McGuire LJ, Huang DP, Teoh R, Arnold M, Wong K, Lee JC. Epstein-Barr virus genome in thymoma and thymic lymphoid hyperplasia. Am J Pathol. 1988;131(3):385-90.

3. Inghirami G, Chilosi M, Knowles DM. Western thymomas lack Epstein-Barr virus by Southern blotting analysis and by polymerase chain reaction. Am J Pathol. 1990;136(6):1429-36.

4. Sanjuan N, Porras A, Otero J, Perazzo S. Expression of major capsid protein VP-1 in the absence of viral particles in thymomas induced by murine polyomavirus. J Virol. 2001;75(6):2891-9. doi:10.1128/JVI.75.6.2891-2899.2001.

5. Wirth JJ, Fluck MM. Immunological elimination of infected cells as the candidate mechanism for tumor protection in polyomavirus-infected mice. J Virol. 1991;65(12):6985-8.

6. Rennspiess D, Pujari S, Keijzers M, Abdul-Hamid MA, Hochstenbag M, Dingemans A et al. Detection of Human Polyomavirus 7 in human thymic epithelial tumors. J Thorac Oncol. 2014. doi:10.1097/JTO.0000000000000390

7. Schowalter RM, Pastrana DV, Pumphrey KA, Moyer AL, Buck CB. Merkel cell polyomavirus and two previously unknown polyomaviruses are chronically shed from human skin. Cell Host Microbe. 2010;7(6):509-15. doi:10.1016/ j.chom.2010.05.006.

8. Van Ghelue M, Khan MT, Ehlers B, Moens U. Genome analysis of the new human polyomaviruses. Rev Med Virol. 2012;22(6):354-77. doi:10.1002/ rmv.1711.

9. Siebrasse EA, Reyes A, Lim ES, Zhao G, Mkakosya RS, Manary MJ, et al. Identification of MW polyomavirus, a novel polyomavirus in human stool. J Virol. 2012;86(19):10321-6. doi:10.1128/JVI.01210-12.

10. DeCaprio JA, Garcea RL. A cornucopia of human polyomaviruses. Nat Rev Microbiol. 2013;11(4):264-76. doi:10.1038/nrmicro2992.

11. Feng $H$, Shuda $M$, Chang $Y$, Moore PS. Clonal integration of a polyomavirus in human Merkel cell carcinoma. Science. 2008;319(5866):1096-100. doi:10.1126/science.1152586.

12. Foulongne V, Kluger N, Dereure O, Brieu N, Guillot B, Segondy M. Merkel cell polyomavirus and Merkel cell carcinoma, France. Emerg Infect Dis. 2008;14(9):1491-3. doi:10.3201/eid1409.080651.

13. Shuda M, Feng H, Kwun HJ, Rosen ST, Gjoerup O, Moore PS, et al. T antigen mutations are a human tumorspecific signature for Merkel cell polyomavirus. Proc Natl Acad Sci U S A. 2008;105(42):16272-7. doi:10.1073/pnas.0806526105.

14. Houben R, Adam C, Baeurle A, Hesbacher S, Grimm J, Angermeyer S, et al. An intact retinoblastoma protein-binding site in Merkel cell polyomavirus large T antigen is required for promoting growth of Merkel cell carcinoma cells. Int J Cancer. 2012;130(4):847-56. doi:10.1002/ijc.26076.

15. Pipas JM, Levine AJ. Role of $\mathrm{T}$ antigen interactions with p53 in tumorigenesis. Semin Cancer Biol. 2001;11(1):23-30. doi:10.1006/ scbi.2000.0343

16. Harms PW, Patel RM, Verhaegen ME, Giordano TJ, Nash KT, Johnson CN, et al. Distinct gene expression profiles of viral- and nonviral-associated merkel cell carcinoma revealed by transcriptome analysis. J Invest Dermatol. 2013;133(4):936-45. doi:10.1038/jid.2012.445.

17. DeCaprio JA. How the Rb tumor suppressor structure and function was revealed by the study of Adenovirus and SV40. Virology. 2009;384(2):274-84. doi:10.1016/j.virol.2008.12.010.

18. Rozenblatt-Rosen O, Deo RC, Padi M, Adelmant G, Calderwood MA, Rolland T, et al. Interpreting cancer genomes using systematic host network perturbations by tumour virus proteins. Nature. 2012;487(7408):491-5. doi:10.1038/nature11288.

19. Berrios C, Jung J, Primi B, Wang M, Pedamallu C, Duke F, et al. Malawi polyomavirus is a prevalent human virus that interacts with known tumor suppressors. J Virol. 2015;89(1):857-62. doi:10.1128/JVI.02328-14.

20. Felsani A, Mileo AM, Paggi MG. Retinoblastoma family proteins as key targets of the small DNA virus oncoproteins. Oncogene. 2006;25(38):5277-85. doi:10.1038/sj.onc.1209621. 
21. Cufi P, Soussan P, Truffault F, Fetouchi R, Robinet M, Fadel E, et al. Thymoma-associated myasthenia gravis: On the search for a pathogen signature. J Autoimmun. 2014;52:29-35. doi:10.1016/j.jaut.2013.12.018.

22. Dehn D, Torkko KC, Shroyer KR. Human papillomavirus testing and molecular markers of cervical dysplasia and carcinoma. Cancer. 2007;111(1):1-14. doi:10.1002/cncr.22425. Hirabayashi H, Fujii Y, Sakaguchi M, Tanaka H, Yoon HE, Komoto Y, et al. p16INK4, pRB, p53 and cyclin D1 expression and hypermethylation of CDKN2 gene in thymoma and thymic carcinoma. Int J Cancer. 1997;73(5):639-44.

23. Omatsu M, Kunimura T, Mikogami T, Shiokawa A, Masunaga A, Nagai T, et al. Cyclin-dependent kinase inhibitors, p16 and p27, demonstrate different expression patterns in thymoma and thymic carcinoma. Gen Thorac Cardiovasc Surg. 2014;62(11):678-84. doi:10.1007/s11748-014-0437-3.

24. Rosai J. Histological typing of tumour of the thymus (ed 2nd). Berlin and Heidelberg: Springer-Verslag; 1999.

25. Masaoka A. Staging system of thymoma. J Thorac Oncol. 2010;5(10 Suppl 4):S304-12. doi:10.1097/JTO.0b013e3181f20c05.

26. Redman R, Rufforny I, Liu C, Wilkinson EJ, Massoll NA. The utility of p16(Ink4a) in discriminating between cervical intraepithelial neoplasia 1 and nonneoplastic equivocal lesions of the cervix. Arch Pathol Lab Med. 2008;132(5):795-9. doi:10.1043/1543-2165(2008)132[795:TUOPID]2.0.CO;2.

27. Klingenberg B, Hafkamp HC, Haesevoets A, Manni JJ, Slootweg PJ, Weissenborn SJ, et al. p16 INK4A overexpression is frequently detected in tumour-free tonsil tissue without association with HPV. Histopathology. 2010;56(7):957-67. doi:10.1111/j.1365-2559.2010.03576.x.

28. Detterbeck FC, Nicholson AG, Kondo K, Van Schil P, Moran C. The Masaoka-Koga stage classification for thymic malignancies: clarification and definition of terms. J Thorac Oncol. 2011;6(7 Suppl 3) S1710 


\section{Chapter}

\section{Oncogenic viruses in Skull Base Chordomas}

Youssef Yakkioui ${ }^{1,2}$; ; Ernst-Jan M. Speel ${ }^{3,4}$; Jacobus J. Van Overbeeke ${ }^{1,2}$; Merel J.M. Boderie $^{5}$; Sreedhar Pujari ${ }^{3,4}$; Axel Zur Hausen ${ }^{3,4}$; Petra F.G. Wolffs ${ }^{6 \#}$; Yasin Temel ${ }^{1,2 \#}$. 


\section{Abstract}

Background: Chordomas are rare tumors assumed to derive from notochordal remnants. We believe that a molecular switch is responsible for their malignant behavior. The involvement of oncogenic viruses has not been studied, however. Thus, in the present study, we investigated the presence of oncogenic viruses in chordomas.

Methods: DNA and RNA from snap-frozen chordoma ( $\mathrm{n}$ [ 18) and chondrosarcoma (n [ 15) specimens were isolated. Real-time PCR or RT-PCR was performed to assess the presence of multiple oncogenic viruses, including herpesviridea (herpes simplex virus [HSV]-1, HSV-2, Epstein-Barr virus [EBV], cytomegalovirus, human herpes-virus [HHV]- 6, $\mathrm{HHV}-7$, and Kaposi's sarcoma associated herpesvirus), polyomaviridea (BK virus, JC virus, Simian virus 40, Merkel cell polyomavirus, human polyomavirus [HPyV]-6, and HPyV-7), papillomaviridae, respiratory viruses and parvovirus B19 [PVB19]. Immunohistochemistry (IHC) and in situ hybridization (ISH) were used to validate the positive results.

Results: PVB19 DNA was detected in 4 of 18 chordomas (22\%) and in 1 of 15 chondrosarcomas (7\%). IHC recognizing the VP2 capsid protein of PVB19 showed a positive cytoplasmic staining in 44\% of the cases (14 of 32). HHV7 DNA was present in 6 of the 18 chordomas (33\%). Genomic DNA of EBV was found in 22\% of the samples; however, no positive results were found on $\mathrm{ISH}$. None of the chordoma cases showed any presence of DNA from the remaining viruses.

Conclusions: Viral involvement in the etiology of chordomas is likely, with PVB19 the most distinguishing.

Key words: Cancer, Chondrosarcoma, Chordoma, Oncogenic virus, PVB19, Virus.

\section{Abbreviations and Acronyms:}

CMV: Cytomegalovirus

EBV: Epstein-Barr virus

HHV: Human herpesvirus

HPV: Human papillomavirus

HPyV: Human polyomavirus

HSV: Herpes simplex virus

ISH: In situ hybridization

KSHV: Kaposi's sarcoma-associated herpesvirus

MCPyV: Merkel cell polyomavirus

PVB19: Parvovirus B19

TMA: Tissue microarray 


\section{Introduction}

Chordoma is a rare neoplasm that is believed to originate from remnants of notochordal cells, located almost exclusively in the axial skeleton. Long-term management of these tumors is limited, given that a high percentage of patients will experience regrowth of the tumor after multimodal therapy. Due to this predicament, research over the last decade has focused on the etiology of chordoma tumors in the hope of revealing biomarkers that can enhance our understanding of tumor growth and treatment management. A widely accepted view is that notochordal cells develop into chordomas subsequent to a benign notochordal tumor stage. ${ }^{1}$ The pathophysiological mechanism underlying this switch from indolent cells to malignant local invasive behavior is unknown. However, while consolidated knowledge is accumulating on the role of cellular and molecular mechanisms responsible for this malignant phenotype, no attempt has yet been made to investigate the involvement of cancer-related viruses in chordomas.

Viral infections are an important etiological factor in the development of many tumors and are therefore a common target for investigation. A small group of oncogenic viruses (oncoviruses), including hepatitis viruses, human papillomaviruses (HPVs), human herpesviruses (HHVs), parvoviruses, and human polyomaviruses (HPyVs), are known to be responsible for a large proportion of virus-related cancers. ${ }^{2,3}$ Such infectious agents are estimated to be responsible for $12 \%-15 \%$ of human tumors worldwide and to account for approximately $20 \%$ of cancer-related deaths. ${ }^{4-7}$ Although the exact mechanisms by which oncoviruses induce malignant biological behavior has yet to be unraveled, one proposal assumes causation by dysregulation of apoptosis due to genetic and epigenetic mechanisms. ${ }^{5,8-10} \mathrm{~A}$ viral etiology for chordomas may be plausible, given that merely a fraction of the patients with notochordal remnants develop a malignant chordoma phenotype. In addition, Stephens et al. ${ }^{11}$ described the existence of chromosomal instability in chordomas and proposed a single crisis as responsible for this phenomenon, otherwise known as chromothripsis. Because viruses have been implicated in the induction of chromosomal instability, a possible association has been investigated. ${ }^{12,13}$

In the present study, we examined the incidence of the most prevalent oncoviruses in skull base chordomas, their control tis-sues, and chondrosarcomas. The viruses under investigation include the hepatitis B virus, hepatitis C virus, HPVs, Merkel cell polyomavirus (MCPyV), and HHVs, including herpes simplex virus (HSV)-1/2 (HHV-1/2) Epstein-Barr virus (EBV; HHV-4), cytomegalovirus (CMV; HHV-5), HHV-7, and Kaposi's sarcoma-associated herpesvirus (KSHV; HHV-8). In addition, we also examined the involvement of HPyV-6 and -7, JC virus, BK virus, Simian virus 40 and also parvovirus B19 (PVB19). 


\section{Materials and methods}

\section{Tumor Tissues and DNA/RNA Isolation}

Snap-frozen tissue specimens from 18 skull base chordomas and 15 chondrosarcomas were collected from surgeries performed at the Neurosurgery Department, Maastricht University Medical Center. Normal tissue, consisting of either bone or fat tissue removed for surgical exposure, was also collected from these surgeries. A tissue microarray (TMA) was generated from 32 formalin-fixed, paraffin-embedded blocks from 24 patients with chordomas, obtained from the Maastricht Pathology Tissue Collection. The storage and use of tissue and patient data were conducted in accordance with the Code for Proper Secondary Use of Human Tissue in The Netherlands (http://www.fmwv.nl). The use of tissue was approved by the local Ethical Committee (METC 16-4-267). DNA and RNA isolation were performed using TRIzol reagent (Thermo Fisher Scientific, Waltham, Massachusetts, USA), according to the manufacturer's protocol. To prevent contamination, the isolation of nucleic acids was performed in a specially designed, isolated environment for DNA and RNA extraction. For real-time PCR, all samples were spiked with murine CMV DNA or RNA, which served as an amplification control following extraction.

\section{PCR Analysis for Herpesviruses, BK and JC Viruses, and Respiratory Viruses}

Real-time PCR for all herpesviruses was performed using primers and probes as described previously, ${ }^{14-23}$ with the exception of primers targeting HHV-7, for which the primers and probe consisted of the following nucleotide sequences: forward primer: $5^{0}$ AACGTGATGCCTAACCAAC- $3^{0}$; reverse primer: $5^{0}$-TAGTTCCAGCACTGCAATCG $-3^{0}$; probe: FAM- $5^{0}$-TGTATGCGTGCATTGGAAAGACCG-3 ${ }^{0}$. For respiratory virus detection, a separate reverse-transcription step was performed using TaqMan reverse-transcriptase reagents, random hexamers (Applied Biosystems, Foster City, California, USA), and incubation for 10 minutes at $25 \mathrm{C}$, for 30 minutes at 48 , and finally for 5 minutes at $95 \mathrm{C}$. Consequently, for all targets, the PCR mix consisted of $20 \mathrm{~mL}$ of isolated DNA (or produced CDNA), primers and probes, and 1 ABsolute QPCR Mix (ABgene, Epsom, UK).

The PCR protocol consisted of 15 minutes at 95 C, followed by 42 cycles of 15 seconds at $95 \mathrm{C}$ and 1 minute at $60 \mathrm{C}$. All qualitative real-time PCR reactions were performed using an ABI Prism 7900 HT PCR machine (Applied Biosystems, Foster City, California, USA), and $\mathrm{Ct}$ values were determined using a threshold value of 0.05 and automatic baselining. The quality of the assays was ensured by positive and negative controls, as well as by a test on amplification inhibition in each sample by an external amplification control. DNA or RNA controls served as positive controls. Artificial DNA controls were constructed by cloning the PCR product into pGEM-3Z vectors, culturing of Escherichia coli containing 
the construct and subsequent plasmid isolation. The isolated plasmids were used as artificial DNA controls. For the generation of artificial RNA controls, RNA was initially constructed using pGEM-3Z vectors containing T7 RNA polymerase promoters flanking the multiple cloning region (Promega, Leiden, The Netherlands) into which the respective amplicons were cloned. Subsequently, RNA constructs containing the amplicons were generated and used as artificial RNA controls using T7 RNA polymerase.

\section{PCR Analysis for HPVs}

Analysis for HPVs was performed as described previously using GP5p/6p-mediated PCR. ${ }^{24-}$ ${ }^{27}$ In short, a step at $94 \mathrm{C}$ for 4 minutes, 40 cycles of $94 \mathrm{C}$ for 1 minute, $40 \mathrm{C}$ for 2 minutes, and $72 \mathrm{C}$ for 1.3 minutes, and then a final step at $72 \mathrm{C}$ for 4 minutes were completed on the PTC-200 PCR apparatus (Bio-Rad, APP/ PCR-001). Acrylamide gels were analyzed using a microplate reader (Bio-Rad). For the assessment, both high-risk and low-risk HPVpositive controls were applied.

\section{PCR Analysis for Polyomaviruses}

Detection of Simian virus 40 was performed using previously published primers with the following PCR conditions: 10 minutes at 94 C, 40 cycles of 30 seconds at 94 C, 30 seconds at $55 \mathrm{C}, 45$ seconds at $72 \mathrm{C}$, and 7 minutes at 72 C. ${ }^{28}$ The positive control was kindly provided by Dr. Verschoor from the Biomedical Primate Research Centre, Rijswijk, The Netherlands. RT-PCR for MCPyV (VP1 and M antigens), HPyV-6, and HPyV-7 were performed as described by Schowalter et al. ${ }^{29}$ and Schrama et al. ${ }^{30}$

\section{Immunohistochemistry and PCR Analysis for PVB19}

Real-time PCR for PVB19 was performed with primers and a TaqMan probe as described by Dennert et al. ${ }^{31}$ The PCR mix consisted of $20 \mathrm{~mL}$ of isolated DNA, a final concentration of $600 \mathrm{nM}$ of each primer, and $200 \mathrm{nM}$ of the probe and 1 ABsolute QPCR Mix. All realtime PCR reactions were performed in an ABI Prism 7900 PCR machine and quantified using a standard curve. The PCR assay used had a linear quantitative range from $10^{7}$ copies to $110^{2}$ with a detection probability $>95 \%$. Below this range, semiquantitative detection was performed by extrapolation of the standard curve. The quality of the assays was ensured by positive and negative controls, as well as by a test on amplification inhibition in each sample with an additional external amplification control. For quantification of viral loads, standard curves were included for each run.

Immunohistochemistry (IHC) analyses were performed using the EnVision FLEX Mini Kit (Agilent Technologies, Santa Clara, California, USA) using an indirect method.32,33 Slides were cut to 4-m thickness, adhered to Superfrost Plus Micro Slides (VWR, Radnor, Pennsylvania, USA), deparaffinized, and subjected to antigen retrieval using Tris/EDTA Target Retrieval solution buffer, pH 9 (Agilent Technologies) for 20 minutes at $97 \mathrm{C}$. 
Endogenous peroxidase activity was quenched with 3\% $\mathrm{H} 2 \mathrm{O} 2$ for 30 minutes. After overnight incubation at 4 C with primary anti-PVB19 anti-body (1:100 MAB8293, VP2 capsid protein; Millipore Sigma, Darmstadt, Germany), the secondary antibody horseradish peroxidase conjugated goat anti-mouse/rabbit (EnVision FLEX, High pH, K801021-2, Agilent-Dako) was incubated for 2 hours at room temperature. Peroxidase activity was visualized by incubation of the slides in $3,3^{0}$-diaminobenzidine tetrahydrochloride plus chromogen/substrate buffer (EnVision). Counterstaining was per-formed by incubation in haematoxylin and eosin using the Mayer's staining protocol. A positive control sample was acquired from a cardiac biopsy specimen from a patient with chronic dilated cardiomyopathy with a high PVB19 viral load in the heart.

\section{In Situ Hybridization EBV}

Colorimetric in situ hybridization (ISH) was performed manually on 4-mm sections of formalin-fixed, paraffin-embedded biopsy tissue on Superfrost Plus slides using the RNAscope 2.0 Brown Assay Kit (Advanced Cell Diagnostics, Hayward, California, USA). In brief, sections were treated with heat and protease, followed by hybridization with the probe cocktail, which includes 17 pairs of probes within a target region (25e968) of the virus. The development of hybridization was visualized with $3,3^{0}$-dia-minobenzidine (Advanced Cell Diagnostics). Slides were counterstained with 50\% hematoxylin for 2 minutes and then mounted with xylene-based SHUR/Mount (Triangle Biomedical Sciences, Durham, North Carolina, USA).

\section{Results}

PVB19 DNA was identified in 4 of 18 (22\%) chordoma specimens. In contrast, only 1 of 15 (7\%) chondrosarcoma specimens showed a positive signal after 39 PCR cycles. Viral load in the chordoma samples ranged from 104 copies $/ \mathrm{mL}$ to 2196 copies $/ \mathrm{ml}$. The single positive chondrosarcoma sample had 52 copies $/ \mathrm{ml}$. The samples were excised from a group of adult patients with a median age of 51 years (range, $35 \mathrm{e} 75$ years), with an exact 2:1 male to female ratio (12 males, 6 females).

In 4 patients, normal control tissue was also available. For these patients, we assessed whether PCR would detect the presence of PVB19 only in the tumor tissue, or in both the tumor tissue and normal tissue. We found viral involvement in 2 out of the 4 patients (50\%). In both of these patients, viral DNA was found in both normal tissue and tumor tissue.

Of the 32 chordoma tissue cores in the TMA stained for chordoma, positive cytoplasmic staining for parvovirus B19 VP2 capsid protein was seen in 14 (44\%) (Figure 1). The 4 samples that were positive on PCR were from cases in which no formalin-fixed, paraffinembedded material was available at the time of the TMA compilation, and thus a 
correlation could not be evaluated. None of the chordomas tested positive for other parvoviruses (BK virus, JC virus, Simian virus 40, MCPyV, HPyV-6, and HPyV-7) by PCR.

Chordomas were also tested for the presence of herpesviruses. Four of the 18 samples (22\%) were positive for EBV, with copy numbers ranging from 59 to 290/ml. Normal control tissue from the patients with chordomas was used to help determine the specificity of the signal. Our analysis revealed EBV RNA only in the control tissues, and not in the corresponding chordoma tissues of the same patient. ISH analysis for the location of EBV RNA in the tumor samples revealed no RNA (Figure 2).

For HHV-7, in 6 out of 18 patients (33\%), PCR indicated amplified DNA, with copy numbers ranging from 112 to 4985 copies/ml. Similar to EBV, compared with normal tissue from the same patients, HHV-7 was positive in 2 of 4 chordoma samples. Tests of other herpesviruses, including CMV, HHV-1/2, HHV-6, and HHV-8, as well as the aforementioned respiratory viruses, did not show the presence of viral DNA in the chordoma samples. Tables 1 and 2 provide an overview of the positive results.

When considering all the expression data presented, it is to be noted that at least 1 of the 3 viruses-PVB19, EBV, or HHV-7-was present in one-half of all the chordoma specimens analyzed. In 2 specimens, all 3 viruses were expressed.
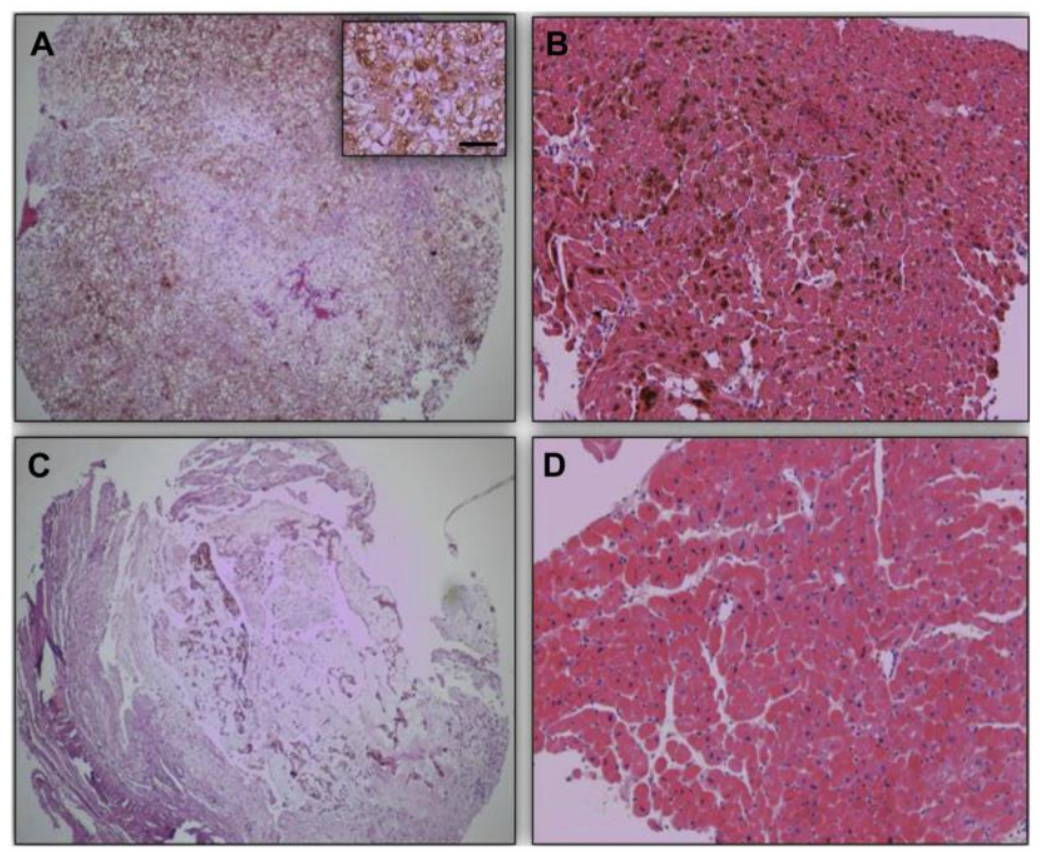

Figure 1. A light microscopy microphotograph at 100 magnification of a chordoma tissue and cardiac muscle biopsy specimen stained for parvovirus B19 VP2 capsid protein (hematoxylin and eosin counterstain). (A and C) Positive and negative staining in chordoma samples. (B and D) Positive and negative control tissue. (Scale bar: $50 \mathrm{~mm}$.) 

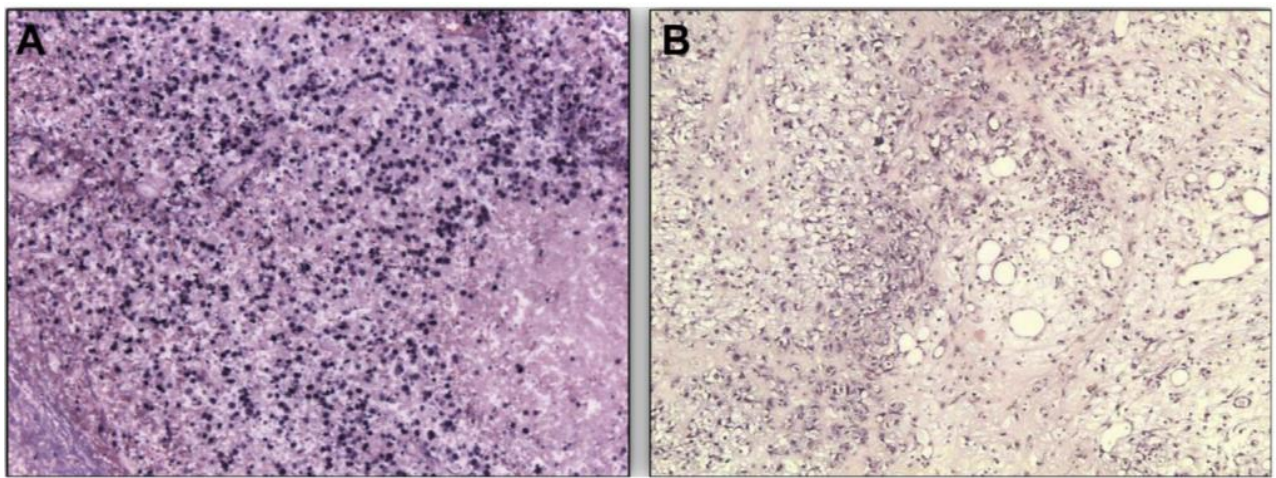

Figure 2. In situ hybridization of Epstein-Barr virus in chordoma. (A) Positive control of nasopharyngeal carcinoma. (B) Negative staining in a chordoma sample. (Hematoxylin and eosin counterstain.)

Table 1. Results from PVB19, HHV-7, and EBV PCR Analysis in 18 Chordoma Specimens and 15 Chondrosarcoma Specimens

\begin{tabular}{|c|c|c|c|c|c|c|}
\hline \multirow[b]{2}{*}{ Tumor Type } & \multicolumn{2}{|l|}{ PVB19 } & \multicolumn{2}{|l|}{$\mathrm{HHV}-7$} & \multirow{2}{*}{$\begin{array}{l}\text { EBV } \\
\text { Positive }\end{array}$} & \multirow[b]{2}{*}{ Negative } \\
\hline & Positive & Negative & Positive & Negative & & \\
\hline Chordoma, $\mathrm{n}$ & 4 & 14 & 6 & 12 & 4 & 14 \\
\hline Chondrosarcoma, $\mathrm{n}$ & 1 & 14 & 0 & 2 & 0 & 2 \\
\hline
\end{tabular}

PVB19, parvovirus B19; HHV-7, human herpesvirus 7; EBV, Epstein-Barr virus; PCR, polymerase chain reaction

Table 2. Results of PCR Performed on Normal and Tumor Tissue from the Same Patient

\begin{tabular}{lllll}
\hline Patient & Sample & PVB19 $(\mathrm{c} / \mathrm{mL})$ & HHV-7 $(\mathrm{c} / \mathrm{mL})$ & EBV $(\mathrm{c} / \mathrm{mL})$ \\
\hline Patient 1 & Normal & 1186 & 360 & 800 \\
Primary & Tumor & 91 & - & - \\
Patient 1 & Normal & 2621 & - & - \\
Recurrent & Tumor & 63 & - & - \\
Patient 2 & Normal & - & 1800 & 300 \\
& Tumor & - & - & - \\
Patient 3 & Normal & - & - & - \\
& Tumor & - & - & - \\
Patient 4 & Normal & 153 & - & - \\
& Tumor & - & - & - \\
\hline
\end{tabular}

Two sample moments (primary resection and resection of a recurrent chordoma) were available for patient 1. PCR, polymerase chain reaction; PVB19, parvovirus B19; HHV-7, human herpesvirus 7; EBV, Epstein-Barr virus. 


\section{Discussion}

Chordomas are believed to originate from notochordal remnants, which are present in $2 \%$ of adults. The scarce nature of this tumor and chromosomal distortion indicate a possible malignant switch in phenotype in these remnants, resulting in chordomagenesis. One of the potential mechanisms by which tumor formation can occur is through the involvement of oncogenic viruses. Approximately $15 \%$ of all human tumors are caused by viruses, involving intricate processes that remain incompletely understood. ${ }^{5}$

Here we describe, for the first time, the relationship of well-known oncogenic viruses and their occurrence in chordoma tissue samples. One of the most recently discovered oncogenic viruses, PVB19 was discovered in 1975 in healthy blood donors and was later related to the existence of erythema infectiosum as the causative agent. Later the virus was associated with other pathologies, including papillary thyroid carcinoma and germ cell tumors. ${ }^{34-37}$ In our cohort, the PVB19 genome was found in 22\% of the chordoma specimens, compared with only $7 \%$ of the chondrosarcoma samples. In 4 of these patients, viral DNA was also detected in one-half of the normal surrounding tissues, indicating a larger area of previous infection. The prevalence of PVB19 infection, determined by the presence of $\operatorname{IgG}$ and $\operatorname{IgM}$, is high in the general adult population, $70 \% \mathrm{e} 80 \%$, and highest in the elderly population. ${ }^{38-40}$ However, the presence of DNA in normal tissues and blood is very rare, with reported rates ranging from 0 to $10 \% .{ }^{40-44}$ Thus, an incidence of $22 \%$ for chordomas in contrast to chondrosarcomas and the general public is significantly higher. In addition, IHC staining showed a high percentage of positive samples, demonstrating that focal positivity of PVB19 in chordomas is not an uncommon finding. In chordomas, early PVB19 infection might explain the chromothripsis observed and thus could be responsible in part for the switch in notochordal remnants leading to chordomagenesis. ${ }^{1}$ Another potential mechanism could be an effect of PVB19 on the phenotype of the established tumor, either contributing to its progression rather than causing the carcinogenesis or causing impairment of the cancer cells, making them resistant to chemotherapeutic drugs. ${ }^{45}$ Finally, viral infection might be an opportunistic infection due to iatrogenic immunosuppression. However, considering that this phenomenon has not been observed in patients undergoing organ transplantation, such a concept is unconvincing. ${ }^{41,44,46}$ Thus, a more comprehensive investigation of the potential role of PVB19 in a larger cohort of chordoma samples with regard to its role in carcinogenesis, chemo-resistance, and prognosis is needed.

Herpesviruses are implicated in the pathophysiology of many cancers. ${ }^{47,48}$ However, in contrast to HSV-1 and HSV-2, little is known about the contribution of HHV-7 to the etiology of cancer. HHV-7 was discovered in 1990, and an active infection has since been related to exanthema subitum in children. In addition to the skin, HHV-7 has an apparent predilection for the central nervous system, considered to be related to febrile seizures as well as viral DNA, being present in $14 \%$ of primary brain tumors. ${ }^{49}$ In line with this 
observation, our present cohort, 33\% of the resected chordomas contained the HHV-7 genome. Given the location of skull base chordomas in the clival region, close to the sphenoid sinus, and the almost absent detection of HHV-7 in other internal organs, potential contamination of notochordal remnants by HHV-7 might be occurring. ${ }^{50}$ Considering the ubiquitous nature of HHV-7 in human saliva and mandibular glands, this likely explains its existence in bony structures surrounding the tumor.

In contrast to HHV-7, EBV has been extensively studied and has well-recognized associations with a multitude of tumors, including Burkitt's lymphoma, gastric cancer, breast cancer, and nasopharyngeal cancer. Variable positive fractions of these tumors contain EBV DNA, ranging from $10 \% \mathrm{e} 16 \%$ in conventional gastric adenocarcinomas to $10 \%$ e $51 \%$ in breast tumors. ${ }^{51}$ The difference in persistent EBV infection reported could be explained by the heterogenetic presence of the virus in tissue when examined by ISH analysis and the potential of EBV to persist lifelong in the memory B-cell compartment. ${ }^{52}$ With this in mind, the presence of EBV in chordomas merits further investigation, with the contrast between positive results in EBV PCR and negative results in EBV ISH possibly explained by heterogeneity in the samples or the presence of EBV in neighboring nonneoplastic cells, termed bystander cells.

In conclusion, our present study indicates the prevalence of oncogenic viruses in chordomas, with variable presence of genomic DNA of BPV19, EBV, and HHV7 in our cohort. One-half of our patients demonstrated the presence of genomic DNA of at least 1 of these 3 viruses. These findings support the idea of the potential involvement of viruses in the etiology of chordomas. 


\section{References}

1. Yakkioui Y, van Overbeeke JJ, Santegoeds R, van Engeland M, Temel Y. Chordoma: the entity. Biochim Biophys Acta. 2014;1846:655-669.

2. Dalianis T, Hirsch HH. Human polyomaviruses in disease and cancer. Virology. 2013;437:63-72.

3. Parkin DM. The global health burden of infection- associated cancers in the year 2002. Int J Cancer. 2006;118:3030-3044.

4. GLOBOCAN 2008. International Agency for Research on Cancer. Cancer fact sheets. Available at: http://globocan.iarc.fr/Pages/fact_sheets_cancer. aspx. Accessed December 5, 2017.

5. Butel JS. Viral carcinogenesis: revelation of mo- lecular mechanisms and etiology of human dis- ease. Carcinogenesis. 2000;21:405-426.

6. Schiller JT, Lowy DR. Vaccines to prevent in- fections by oncoviruses. Annu Rev Microbiol. 2010; 64:23-41.

7. zur Hausen H. Infections Causing Human Cancer (e- book). Hoboken, NJ: Wiley-Blackwell; 2007.

8. Fuentes-González AM, Contreras-Paredes A, Manzo-Merino J, Lizano M. The modulation of apoptosis by oncogenic viruses. Virol J. 2013;10: 182.

9. Flanagan JM. Host epigenetic modifications by oncogenic viruses. Br J Cancer. 2007;96:183-188.

10. Moore PS, Chang Y. Why do viruses cause cancer? Highlights of the first century of human tumour virology. Nat Rev Cancer. 2010;10:878-889.

11 Stephens PJ, Greenman CD, Fu B, Yang F, Bignell GR, Mudie LJ, et al. Massive genomic rearrangement acquired in a single catastrophic event during cancer development. Cell. 2011;144: 27-40.

12. Gao P, Zheng J. Oncogenic virus-mediated cell fusion: new insights into initiation and progres- sion of oncogenic virus-related cancers. Cancer Lett. 2011;303:1-8.

13. Duelli DM, Padilla-Nash HM, Berman D, Murphy KM, Ried T, Lazebnik Y. A virus causes cancer by inducing massive chromosomal insta- bility through cell fusion. Curr Biol. 2007;17: 431-437.

14. Goossens VJ, Wolffs PF, van Loo IH, Bruggeman CA, Verbon A. CMV DNA levels and CMV gB subtypes in ART-naive HAART-treated patients: a 2-year follow-up study in The Netherlands. AIDS. 2009;23:14251429.

15. Gunson RN, Collins TC, Carman WF. Real-time RT-PCR detection of 12 respiratory viral infections in four triplex reactions. J Clin Virol. 2005;33: 341-344.

16. Real-time quantitative analysis of polyoma BK viremia and viruria in renal allograft recipients. J Virol Methods. 2002;103:51-56

17. Niesters HG, van Esser J, Fries E, Wolthers KC, Cornelissen J, Osterhaus AD. Development of a real-time quantitative assay for detection of Epstein-Barr virus. J Clin Microbiol. 2000;38:712-715.

18. Ryschkewitsch C, Jensen P, Hou J, Fahle G, Fischer S, Major EO. Comparison of PCR- southern hybridization and quantitative real-time PCR for the detection of JC and BK viral nucleo- tide sequences in urine and cerebrospinal fluid. J Virol Methods. 2004;121:217-221.

19. Templeton KE, Scheltinga SA, Beersma MF, Kroes AC, Claas EC. Rapid and sensitive method using multiplex real-time PCR for diagnosis of infections by influenza A and influenza B viruses, respiratory syncytial virus, and parainfluenza vi- ruses 1, 2, 3, and 4. J Clin Microbiol. 2004;42: 1564-1569.

20. van der Vries E, Jonges M, Herfst S, Maaskant J, Van der Linden A, Guldemeester J, et al. Evalua- tion of a rapid molecular algorithm for detection of pandemic influenza A (H1N1) 2009 virus and screening for a key oseltamivir resistance (H275Y) substitution in neuraminidase. J Clin Virol. 2010; 47:34-37.

21. van Doornum GJ, Guldemeester J, Osterhaus AD, Niesters HG. Diagnosing herpesvirus infections by realtime amplification and rapid culture. J Clin Microbiol. 2003;41:576-580.

22. van Elden $L$, Nijhuis $M$, Schipper $P$, Schuurman $R$, van Loon AM. Simultaneous detection of influenza viruses A and B using real- time quantitative PCR. J Clin Microbiol. 2001;39: 196-200.

23. Watzinger F, Suda M, Preuner S, Baumgartinger R, Ebner K, Baskova L, et al. Real- time quantitative PCR assays for detection and monitoring of pathogenic human viruses in immunosuppressed pediatric patients. J Clin Microbiol. 2004;42:5189-5198. 
24. van den Brule AJ, Pol R, Fransen-Daalmeijer N, Schouls LM, Meijer CJ, Snijders PJ. GP5p/6p PCR followed by reverse line blot analysis enables rapid and high-throughput identification of human papillomavirus genotypes. J Clin Microbiol. 2002;40: 779-787.

25. Jacobs MV, Snijders PJ, Voorhorst FJ, Dillner J, Forslund O, Johansson B, et al. Reliable high-risk HPV DNA testing by polymerase chain reaction: an intermethod and intramethod comparison. J Clin Pathol. 1999;52:498-503.

26. Jacobs MV, Snijders PJ, van den Brule AJ, Helmerhorst TJ, Meijer CJ, Walboomers JM. A general primer GP5 /GP6( )-mediated PCR- enzyme immunoassay method for rapid detection of 14 high-risk and 6 lowrisk human papilloma- virus genotypes in cervical scrapings. J Clin Microbiol. 1997;35:791-795.

27. Olthof NC, Huebbers CU, Kolligs J, Henfling M, Ramaekers FC, Cornet I, et al. Viral load, gene expression and mapping of viral integration sites in HPV16-associated HNSCC cell lines. Int J Cancer. 2015;136:E207E218.

28. Campello C, Comar M, Zanotta N, Minicozzi A, Rodella L, Poli A. Detection of SV40 in colon cancer: a molecular case-control study from northeast Italy. J Med Virol. 2010;82:1197-1200.

29. Schowalter RM, Pastrana DV, Pumphrey KA, Moyer AL, Buck CB. Merkel cell polyomavirus and two previously unknown polyomaviruses are chronically shed from human skin. Cell Host Microbe. 2010; 7:509515.

30. Schrama D, Buck CB, Houben R, Becker JC. No evidence for association of HPyV6 or HPyV7 with different skin cancers. J Invest Dermatol. 2012;132: 239-241.

31. Dennert R, Velthuis S, Schalla S, Eurlings L, van Suylen RJ, van Paassen $P$, et al. Intravenous immunoglobulin therapy for patients with idio- pathic cardiomyopathy and endomyocardial biopsy-proven high PVB19 viral load. Antivir Ther. 2010;15:193-201.

32. Chen X, Cho DB, Yang PC. Double- staining immunohistochemistry. N Am J Med Sci. 2010;2: 241-245.

33. Ramos-Vara JA. Technical aspects of immuno- histochemistry. Vet Pathol. 2005;42:405-426.

34. Adamson LA, Fowler L, Clare-Salzler MJ, Hobbs JA. Parvovirus B19 infection in Hashimo- to's thyroiditis, papillary thyroid carcinoma, and anaplastic thyroid carcinoma. Thyroid. 2011;21: 411-417.

35. Wang JH, Zhang WP, Liu HX, Wang D, Li YF, Wang WQ, et al. Detection of human parvovirus B19 in papillary thyroid carcinoma. Br J Cancer. 2008;98:611-618.

36. Kerr JR, Barah F, Cunniffe VS, Smith J, Vallely PJ, Will AM, et al. Association of acute parvovirus B19 infection with new onset of acute lymphoblastic and myeloblastic leukaemia. J Clin Pathol. 2003;56: 873-875.

37. Gray A, Guillou L, Zufferey J, Rey F, Kurt AM, Jichlinski P, et al. Persistence of parvovirus B19 DNA in testis of patients with testicular germ cell tumours. J Gen Virol. 1998;79(Pt 3):573-579.

38. Tsujimura M, Matsushita K, Shiraki H, Sato H, Okochi K, Maeda Y. Human parvovirus B19 infection in blood donors. Vox Sanguinis. 1995;69: 206-212.

39. Waldman M, Kopp JB. Parvovirus B19 and the kidney. Clin J Am Soc Nephrol. 2007;(2 Suppl 1): S47-S56.

40. Woolf AD, Campion GV, Chishick A, Wise S, Cohen BJ, Klouda PT, et al. Clinical manifesta-tions of human parvovirus B19 in adults. Arch Intern Med. 1989;149:1153-1156.

41. Eid AJ, Brown RA, Patel R, Razonable RR. Parvovirus B19 infection after transplantation: a review of 98 cases. Clin Infect Dis. 2006;43:40-48.

42. Plentz A, Würdinger M, Kudlich M, Modrow S. Low-level DNAemia of parvovirus B19 (genotypes 1-3) in adult transplant recipients is not associated with anaemia. J Clin Virol. 2013;58:443-448.

43. Heegaard ED, Brown KE. Human parvovirus B19. Clin Microbiol Rev. 2002;15:485-505.

44. Porignaux R, Vuiblet $V$, Barbe $C$, Nguyen $Y$, Lavaud S, Toupance O, et al. Frequent occurrence of parvovirus B19 DNAemia in the first year after kidney transplantation. J Med Virol. 2013;85: 1115-1121.

45. Jacob HE. Chemotherapy for cranial base tumors. J Neurooncol. 1994;20:327-335.

46. Carraturo A, Catalani V, Ottaviani D, Menichelli P, Rossini M, Terella D, et al. Parvovirus B19 infec-tion and severe anemia in renal transplant re-cipients. ScientificWorldJournal. 2012;2012:102829.

47. Alibek K, Baiken Y, Kakpenova A, Mussabekova A, Zhussupbekova S, Akan M, et al. Implication of human herpesviruses in oncogen-esis through immune evasion and supression. Infect Agent Cancer. 2014;9:3.

48. Rafferty KA Jr. Herpes viruses and cancer. Sci Am. 1973;229:26-33. 
49. Chan PK, Ng HK, Cheng AF. Detection of human herpesviruses 6 and 7 genomic sequences in brain tumours. J Clin Pathol. 1999;52:620-623.

50. Kempf W, Adams V, Mirandola P, Menotti L, Di Luca D, Wey N, et al. Persistence of human herpesvirus 7 in normal tissues detected by expression of a structural antigen. J Infect Dis. 1998; 178:841-845.

51. Hippocrate A, Oussaief L, Joab I. Possible role of EBV in breast cancer and other unusually EBV-associated cancers. Cancer Lett. 2011;305:144-149.

52. Babcock GJ, Decker LL, Volk M, Thorley-Lawson DA. EBV persistence in memory B cells in vivo. Immunity. 1998;9:395-404. 

This chapter is embargoed at request

\section{Chapter}

\section{No evidence for WUPyV DNA in human lung} cancers

Sreedhar Pujari, Dorit Rennspiess, Anke Haugg, Ernst-Jan Speel, Axel zur Hausen

In preparation 
This chapter is embargoed at request

\section{Chapter}

\section{Novel degenerate oligonucleotides as discovery tool for human polyomaviruses}

Sreedhar Pujari, Dorit Rennspiess, Ernst-Jan Speel, Axel zur Hausen

In preparation 
This chapter is embargoed at request

Chapter

General Discussion, Summary and

Valorization 
Acknowledgements 
I would like to thank many people without whom this PhD may not have been possible.

First, my love and better half, Prabha I feel very lucky to have you in my life. You have been very supportive and encouraging since our first day together. I do remember the hard times we experienced being apart from each other and sacrifices you have made for this PhD to happen. You have always been my side throughout, during tough times and happiness alike. I can not forget our days in Maastricht, when every day you welcomed me with delicious snacks and dinner after a tireful day at work. You are an amazing cook and I am very fortunate to have tasted that great food you cooked. I am very lucky in past couple of years to have an energetic and happy son, Dheemanth around to make me smile, even when I am going through hard times. My father, Mr. Umapathi and mother, Mrs. Leelavathi, I can not thank you enough for the sacrifices you have made for my education and well being. I always strive to make you two proud and promise to never let you down. I would like to thank my sister, Srilatha for her moral support. Though being an elder sibling, I have learnt how to be strong and supportive of people we love from her. I do remember sacrifices you have made for better future. I love my family, you are awesome.

I would like to thank my promoter/adviser Prof. Dr. Axel zur Hausen for the opportunity to pursue PhD in his lab. I was very fortunate to join your group and acquire knowledge in virology first hand from one of the experts in the field. You have been motivating me to do better all the time and I can not forget the encouraging words which have always kept my spirits high. I clearly remember you showing concern about how I have been doing in my personal life as it was my first time being away from family. I really thank you for your trust in my potential do quality research.

Prof. Ernst-jan Speel, I thank you very much for your support and suggestions during our discussions. I have been fortunate to have you as my promoter as your critical analytical knowledge and insightful ideas have always helped me to acquire knowledge in molecular pathogenesis of viruses. I thank my co-promoter, Dr. V Winnepenninckx for her motivation and suggestions in my research. Your knowledge and insights in clinical pathology has helped me a lot in my research.

I would like to thank my thesis assessment committee: Prof. dr. M.G.J Tilanus, Prof. dr. F.C.S Ramaekers, Prof. dr. P.H.M Savelkoul, Prof. dr. E. Stickeler, Dr. A.J.C van den Brule for their time, consideration, and remarks. I also thank them to assess my thesis at the earliest and making time to be on my defense ceremony.

I Thank my lab mates Dr. Anke Haugg for her support and training during my first days in the lab. Dorit, I thank you very much, without your support I wouldn't have published my article as PhD. I do remember our first meeting, when you came to Maastricht station to receive me on my first day in Netherlands. You have been that same helpful and friendly person I have met on that day. I thank my other lab mates Ruth, Jan, Lisa and Emil making my stay in the lab friendly and knowledgeable with fruitful discussions. I thank my office 
mate Iris, for her friendly advices and suggestions in research. I thank Prof. Manon van Engeland and her group for their suggestions in research and help with experiments in lab. Specifically, I would like to thank Peter for his help in southern blot experiments and Mat for microbial and molecular biology experiments.

I would like to thank my friends Ramesh, Nishanth, Mrinalini, Ajay, Sampath, Kranthi, Subhashis, Deepthi, Ruhi, Jelly, Shilpi, swati, Katrina, Xavier, and Bhavana making my stay in Maastricht very happy and cherishable. I liked our potluck parties on weekends and special dance after few beers. I, especially thank Ramesh for being one of the best hosts I have come across and good company during time away from home. I thank Dr. Anjana, Mr. Anal and their son Aavyan for their hospitality during my visit to their home. I am very thankful to Anjana for her valuable suggestions in research and personal life. You all made Maastricht my home away from home. I think my friends in rest of the Europe during my PhD days, Chiru, Bhupesh, Pinky, Vishnu, Mallu Madhu, Suri, Harsha, Sepali for having me visit their place and giving memories which, I can cherish for my life time.

Heerlen cricket club friends, Nishanth, Vicky, Raj, Swaroop, Mike, Alok, Amaya, Andrew, Zulfi I am thankful to you all for having me in the club and opportunity to play with friendly and talented cricketers like you. I can never forget beer parties we had with Vicky after our match/practice.

I would like to thank all the members of Pathology department at MUMC for their valuable suggestions and remarks during departmental meetings. I thank Cor Beek, Elly, Daniell, Lysette from pathology secretariat for their help and support in administrative part of my PhD at Maastricht University. I would like to thank Danielle also for co ordinating with many people to arrange my promotion. I would like to thank Mario Zwanenberg, Martine Bherghof from KCIC office for their help and support for HR issues and visas to live and work in Netherlands.

I thank GROW school of oncology and developmental biology and Maastricht University to give me an opportunity to to pursue the highest degree in life sciences at one of the emerging universities in the world. I thank great country the Netherlands to provide me the opportunity to live work and experience the dutch culture which I love. Dutch people, you are very warm and welcoming. I would always come back to this wonderful country to have more cherishable memories 



\section{Curriculum vitae}

Sreedhar Pujari born on June $10^{\text {th }}, 1982$ in Raketla village in southern state of Andhra Pradesh, India have spent his childhood and did schooling in Raketla. He did his bachelor's and master's studies in biotechnology at Bangalore and Periyar universities in southern India. During this time, he has developed immense interest in life science research and did summer project at St. Johns medical college and hospital, Bangalore. He has done master's thesis (2005-2007) on microbial and molecular detection of food borne pathogens at Global institute of biotechnology, Hyderabad. His interest in research drove him to secure a junior research assistantship at India's prestigious Indian Institute of Science (IISC) in the year 2008. With the research experience at IISc, he has joined Maastricht University in Nov 2011 for his doctoral studies on "Novel human polyomaviruses in human cancers". During his PhD he has published research articles about his findings in peer reviewed scientific journals and presented his research work at number of international conferences. The results of his research during doctoral studies are presented in this thesis. Since the year Dec 2016, he has been pursuing his postdoctoral research on "Epigenetic regulation of differentiation dependent life cycle of human papillomavirus (HPV)" at Northwestern University, Chicago, USA. He would be joining for his next postdoctoral work at University of North Carolina, Chapel hill, USA in April 2019 to work on "HPV induced head and neck carcinogenesis". 



\section{Publications}

Yakkioui Y, Speel EM, Van Overbeeke JJ, Boderie MJM, Pujari S, Hausen AZ, Wolffs PFG, Temel Y. Oncogenic Viruses in Skull Base Chordomas. World Neurosurg. 2018 Apr; 112: e7-e13.

Pujari S*, Beckervordersandforth J*, Rennspiess D, Speel EJ, Winnepenninckx V, Diaz C, Weyers W, Haugg AM, Kurz AK, zur Hausen A. Frequent detection of Human Polyomavirus 6 in keratoacanthomas. Diagn Pathol. 2016 Jul 7; 11(1):58. (*Equal contribution)

Keijzers M, Rennspiess D, Pujari S, Abdul-Hamid MA, Hochstenbag M, Dingemans AM, Kurz AK' Haugg A, Maessen JG, De Baets MH, zur Hausen A. Expression of pRb and p16INK4 in Human Thymic Epithelial Tumors in relation to the presence of Human Polyomavirus 7. Diagn Pathol. 2015 Nov 4; 10:201.

Pujari $\mathrm{S}^{*}$, Rennspiess $\mathrm{D}^{*}$, Keijzers $\mathrm{M}$, Abdul-Hamid MA, Hochstenbag $\mathrm{M}$, Dingemans $\underline{\text { AM }}$, Kurz AK, Speel EJ, Haugg A, Pastrana DV, Buck CB, De Baets MH, Zur Hausen A. Detection of human polyomavirus 7 in human thymic epithelial tumors. Journal of Thoracic Oncology 2015 Feb; 10(2):360-6. (*Equal contribution)

Bharti SK, Rex K, Sreedhar P, Krishnan N, Varshney U. Chimeras of Escherichia coli and Mycobacterium tuberculosis single-stranded DNA binding proteins: characterization and function in Escherichia coli. PLoS One. 2011; 6(12): e27216.

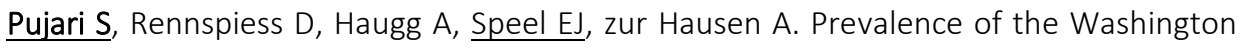
University Polyomavirus in human cancers. (to be Submitted)

Pujari S, Speel EJ, zur Hausen A. Degenerate human polyomavirus primers - tools for diagnostics and discovery of new human polyomaviruses. (to be Submitted)

$\underline{\text { Pujari S*, Rennspiess D* }}$ Abdul-Hamid MA, Speel EJ, Haugg A , Kurz AK, Pastrana DV,$\underline{\text { Buck }}$ $\underline{\mathrm{CB}}$, Zur Hausen A. Detection of human Merkel cell polyomavirus in human thymic epithelial tumors. (*Equal contribution. In preparation) 